Publisher: GSA

Journal: GEOL: Geology

DOI:10.1130/G37262.1

\title{
1 Links between arc volcanoes and porphyry-epithermal ore
}

\section{2 deposits}

3 Olivier Nadeau', John Stix ${ }^{2}$, and Anthony E. Williams-Jones ${ }^{2}$

$4{ }^{1}$ Department of Earth and Environmental Sciences, University of Ottawa, Ottawa,

5 Ontario K1N 6N5, Canada

$6 \quad{ }^{2}$ Department of Earth and Planetary Sciences, McGill University, Montreal, Quebec H3A

$7 \quad 0 E 8$, Canada

8 ABSTRACT

9 Porphyry and epithermal ore deposits, which are the products of magmatic

10 hydrothermal fluids, are intimately associated with volcanoes in continental and island

11 arcs above subduction zones, but the exact nature of this relationship has remained

12 enigmatic. Although metal deposition is usually thought to occur during the waning

13 stages of volcanism, numerous ore deposits have been demonstrated to be syn-volcanic.

14 Here we show how the formation of these deposits is tied to volcanic cycles. We relate

15 the chemical variations in vapors from Merapi volcano, Indonesia, to different stages of

16 its eruptive cycle. The chemical compositions of volcanic vapors from subduction zone

17 volcanoes are then compared globally to those of fluid inclusions from porphyry-

18 epithermal deposits. These data show that adiabatic decompression is the principal

19 control on mineralization. They also suggest that volcanic and sub-volcanic magmatic-

20 hydrothermal systems are under lithostatic pressure during quiescence but decompress

21 rapidly during injections of mafic magma and explosive eruptions. During quiescence,

22 the magma evolves through fractional crystallization and devolatilization, gradually 
Publisher: GSA

Journal: GEOL: Geology

DOI:10.1130/G37262.1

23 becoming oxidized and enriched in gold and other incompatible metals. Upon the

24 injection of sulfur-rich mafic magmas, subvolcanic intrusions brecciate the overlying

25 rocks, the systems are depressurized, the volcanoes erupt explosively, supercritical fluids

26 unmix into vapor and brine, and base metal sulfides precipitate.

\section{INTRODUCTION}

28 Magmatic-hydrothermal ore deposits form over periods ranging from thousands

29 to millions of years (Sillitoe, 2010), a generally shorter lifespan than that of arc volcanoes

30 which are thought to usually remain active for millions of years (Newhall et al., 2000).

31 Although the economic mineralization is usually considered to postdate volcanism

32 (Williams-Jones and Heinrich, 2005), numerous ore deposits have been shown to be

33 genetically associated with volcanism (Hattori and Keith, 2001) or even interrupted by

34 episodes of renewed magmatic activity (Maughan et al., 2002). Interestingly, the

35 injection of sulfur-rich mafic magmas into shallow porphyry stocks appears to trigger

36 explosive eruptions (Eichelberger, 1980) and generate ore deposits (Hattori and Keith,

37 2001). This paper reports data on the distribution of metals, sulfur and chlorine in

38 volcanic vapors collected at Merapi volcano during a phase of quiescent degassing in

392004 and after a large explosive eruption in 2006, and compares them to data reported for

40 volcanic vapors globally and for fluid inclusions from porphyry deposits. These data and

41 comparisons provide the first convincing evidence that injections of mafic magma (which

42 commonly coincide with explosive volcanic eruptions) are followed by decompression of

43 the magmatic hydrothermal system, inducing fluid phase separation, rapid cooling and

44 the deposition of porphyry and epithermal ores. In so doing they demonstrate the

45 important links between arc volcanism and porphyry-epithermal ore formation. 
Publisher: GSA

Journal: GEOL: Geology

DOI:10.1130/G37262.1

\section{METHODS}

$47 \quad$ Volcanic vapors were sampled by inserting silica tubes into fumaroles and

48 connecting the tubes to ice-trap condensers. The liquid that collected in the ice trap was

49 analyzed by ICP-MS, ICP-OES, INAA and IC. Sublimates from the vapors were

50 collected by inserting silica tubes into fumaroles immediately after the condensates were

51 sampled and waiting several days until sufficient solid had accumulated on the inner

52 walls of the tubes. Temperatures were measured along the tube centerlines using a

53 thermocouple. Aliquots of sublimates were mounted on polished sections for mineral

54 identification via EMPA and the remainder was analyzed using XRD.

\section{RESULTS}

\section{Vapor Compositions}

57 The concentrations of ligands (S-Cl) and metals ( $\mathrm{Au}-\mathrm{Cu}-\mathrm{Zn}-\mathrm{Pb}-\mathrm{Mo}-\mathrm{Y}-\mathrm{U})$ in

58 condensed vapor were normalized to Na to compensate for variations in density and thus

$59-\mathrm{H}_{2} \mathrm{O}$ of the vapor (Fig. 1a). The vapors were enriched in S-Cl-Pb-Cu-Zn in 2006

60 (explosive) and enriched in Mo-Y-Au-U in 2004 (quiescent). In 2006, S and Cl

61 concentrations in the vapor ranged from 0.7 to $1.0 \mathrm{wt} . \%$ and $0.5-0.7 \mathrm{wt} . \%$, respectively,

62 whereas they varied from 260 to $520 \mathrm{ppm}$ and 890 to $3030 \mathrm{ppm}$, respectively, in 2004

63 (Table 1). Copper and $\mathrm{Zn}$ concentrations ranged from 0.16 to $0.28 \mathrm{ppm}$ and 0.15 to 0.42

$64 \mathrm{ppm}$, respectively, in 2006 and only $0.003 \mathrm{ppm}$ and 0.06 to $0.15 \mathrm{ppm}$, respectively, in

65 2004. By contrast, concentrations of Mo only reached $0.6 \mathrm{ppb}$ in 2006 compared to 4-20

$66 \mathrm{ppb}$ in 2004. The concentrations of $\mathrm{Y}$ were $0.7-4 \mathrm{ppb}$ in 2004 and $0.4-0.5 \mathrm{ppb}$ in 2006,

67 those of Au were 0.2-0.6 ppb in 2004 and $0.02 \mathrm{ppb}$ in 2006, and those of $\mathrm{U}$ were 0.09

$68 \quad 0.34 \mathrm{ppb}$ in 2004 and $0.06-0.08 \mathrm{ppb}$ in 2006. 
Publisher: GSA

Journal: GEOL: Geology

DOI:10.1130/G37262.1

The concentrations of the REE were first normalized to $\mathrm{Na}$ and subsequently to

70 chondrite (McDonough and Sun, 1995) to allow comparison with subduction zone fluids

71 (Fig. 1b). The 'doubly-normalized' REE profiles all show LREE enrichment typical of

72 subduction zone fluids. The vapors from 2004 had higher total REE contents compared to

73 those from 2006. The concentrations of LILE and HFSE were first normalized to $\mathrm{Na}$ and

74 subsequently to MORB (McDonough and Sun, 1995) to evaluate fluid behavior (Fig. 1c).

75 All samples display gradual enrichment of progressively more incompatible elements,

76 except Ti, because it was compatible in titanomagnetite (Camus, 2000; Nadeau et al.,

77 2013). All incompatible elements are enriched in 2004 samples relative to those for 2006,

78 except for $\mathrm{Zr}$ and $\mathrm{Hf}$ in one sample.

\section{Sublimate Mineralogy and Redox State}

80 A variety of minerals precipitated from the vapors during cooling along the silica

81 tubes. In 2004, the mineral assemblage consisted of chlorides, sulfates and hydrated

82 sulfates, oxides and native elements, whereas the minerals comprised chlorides, sulfides,

83 arsenosulfides and native elements in 2006 (Fig. 2; Table DR1).

84 Iron precipitated in ilmenite and hematite in 2004 and in pyrite and smythite in

85 2006, $\mathrm{Pb}$ precipitated as anglesite in 2004 and as galena and tsugaruite $\left(\mathrm{Pb}_{4} \mathrm{As}_{2} \mathrm{~S}_{7}\right)$ in

86 2006, and Bi, Zn-Cd precipitated as bismuthinite and wurtzite-greenockite in 2006. The

87 magmatic-hydrothermal system was thus relatively oxidized in 2004 and reduced in

882006.

89 Magmatic Arc Fluids

90 In order to expand our database beyond that of Merapi and to compare volcanic

91 vapors to ore fluids, we compiled published compositional data for 282 samples of vapor 


\section{Publisher: GSA \\ Journal: GEOL: Geology \\ DOI:10.1130/G37262.1}

92 condensates from 19 subduction zone stratovolcanoes (Table DR2) and 292 fluid

93 inclusion assemblages from seven major porphyry $\mathrm{Cu} \pm \mathrm{Mo} \pm \mathrm{Au}$ deposits (Table DR3)

94 (Fig. 3). These data are illustrated in violin plots showing median (black dot) and

95 interquartile range (black line) values as well as the total data distribution (gray envelope)

96 (see supplementary information). The volcanic vapors ranged in temperature from $85{ }^{\circ} \mathrm{C}$

97 to $1020{ }^{\circ} \mathrm{C}$, averaging $445 \pm 216{ }^{\circ} \mathrm{C}(1 \sigma)$, whereas the fluid inclusions were trapped at

98 temperatures from $220{ }^{\circ} \mathrm{C}$ to $771{ }^{\circ} \mathrm{C}$ or an average of $434 \pm 130{ }^{\circ} \mathrm{C}(1 \sigma)$. On average,

99 base metal concentrations in fluid inclusions from porphyry deposits are more than three

100 orders of magnitude higher than in volcanic vapors. Given their similar temperatures, and

101 experimental studies of metal solubility in aqueous fluids, the higher metal content of the

102 fluid inclusions is attributed to their higher fluid density and resulting higher capacity to

103 hydrate metal complexes. At constant density, metal solubility increases with increasing

104 temperature due to a corresponding increase in the partial pressure of $\mathrm{H}_{2} \mathrm{O}$, which

105 promotes the formation of metal complexes with high hydration numbers (e.g., Migdisov

106 et al., 2014). Increasing temperature, however, destabilizes metal complexes with high

107 hydration numbers, and a maximum solubility is reached when this effect outweighs that

108 of the increasing partial pressure of $\mathrm{H}_{2} \mathrm{O}$. In volcanic emissions, the $\mathrm{Pb} / \mathrm{Na}$ ratio reaches a

109 maximum in fluids with temperatures of $400-600^{\circ} \mathrm{C}, \mathrm{Zn} / \mathrm{Na}$ is greatest in fluids with

110 temperatures of $400-800{ }^{\circ} \mathrm{C}$ and $\mathrm{Cu} / \mathrm{Na}$ and $\mathrm{Au} / \mathrm{Na}$ have maxima in fluids with

111 temperatures of $200-400{ }^{\circ} \mathrm{C}$. The use of $\mathrm{Y}$ as a proxy for the REE suggests that REE/Na

112 ratios are greatest in vapors with temperatures of $400-600{ }^{\circ} \mathrm{C}$ (Fig. 3a).

$113 \mathrm{The} \mathrm{Pb} / \mathrm{Na}, \mathrm{Zn} / \mathrm{Na}$ and $\mathrm{Mo} / \mathrm{Na}$ ratios are much lower in fluid inclusions than in

114 volcanic vapors (Fig. 3b). This probably results from the preferential incorporation of $\mathrm{Na}$ 
Publisher: GSA

Journal: GEOL: Geology

DOI:10.1130/G37262.1

115 in alteration minerals precipitating from the fluid between the porphyry and the

116 fumaroles. By contrast, $\mathrm{Cu} / \mathrm{Na}$ is higher in supercritical and vapor fluid inclusions and

117 lower in brines and volcanic vapors. However, the higher content of $\mathrm{Cu}$ in vapor

118 inclusions has been interpreted to result from post-entrapment diffusion of $\mathrm{Cu}$ toward the

119 vapor inclusions (Lerchbaumer and Audétat, 2012). The $\mathrm{Cu} / \mathrm{Na}$ ratio is thus higher in

120 supercritical fluids than in brines, vapors and volcanic vapors, implying that $\mathrm{Cu}$-bearing

121 minerals undergo largescale precipitation during the unmixing of supercritical fluids into

122 brine and vapor.

\section{DISCUSSION}

\section{Physical State of the Volatile Phase}

125 An important difference between porphyry fluids and volcanic vapors is their

126 physical state. Magmatic volatiles exsolved at pressures and temperatures greater than

127 those of the critical point, i.e., porphyry fluids at depth, are in a supercritical state. When

128 supercritical fluids ascend, they may reach the critical point and unmix into liquid and

129 vapor. Upon unmixing, $\mathrm{Cl}$ preferentially partitions into the liquid forming brine (Bodnar

130 et al., 1985) whereas S partitions preferentially into the vapor that is ultimately emitted as

131 a volcanic gas (Simon and Ripley, 2011; Nadeau et al., 2013).

132 Pressure has a major impact on the physical state of magmatic hydrothermal

133 fluids because decreasing pressure may lead to phase separation. It is possible to relate

134 the pressure at which supercritical fluids unmix into brine and vapor to a critical depth,

135 by assuming lithostatic and hydrostatic pressure gradients. According to experimental

136 studies in the $\mathrm{H}_{2} \mathrm{O}-\mathrm{NaCl}$ system, for a magmatic fluid at $1000{ }^{\circ} \mathrm{C}$ and $5-10 \mathrm{wt} . \% \mathrm{NaCl}_{\text {eq }}$

137 (Zajacz et al., 2008), the critical depth is $5 \mathrm{~km}$ under a lithostatic pressure gradient and 15 
Publisher: GSA

Journal: GEOL: Geology

DOI:10.1130/G37262.1

$138 \mathrm{~km}$ under a hydrostatic pressure gradient (Driesner and Heinrich, 2007). The addition of

$139 \mathrm{CO}_{2}$ and sulfur species to the system will increase this critical depth, but phase

140 relationships in the COHS-NaCl system are not sufficiently known to quantify this effect

141 (Webster and Mandeville, 2007).

142 Variations in Sulfur and Chlorine

143 Porphyry-type deposits have greater contents of sulfur than of the base and

144 precious metals for which they are exploited. At Merapi, volcanic vapors were highly

145 enriched in $\mathrm{S}$ following the explosive eruption of 2006 compared to volcanic vapors that

146 were quiescently degassed in 2004 (Table 1). The total concentration of S in vapor

147 condensates was 6730 and 10,580 ppm in 2006, and 260 and 520 ppm in 2004; the higher

148 concentration of 2006 was attributed to the injection of sulfide melt-saturated mafic

149 magma in that year (Nadeau et al., 2010). Chlorine was present in significant

150 concentrations in volcanic vapors released from Merapi in both 2004 and 2006, but its

151 concentration varied much less than that of sulfur between periods of quiescence and

152 eruption.

\section{Redox Conditions}

154 During periods of quiescent degassing, magma becomes oxidized due to the

155 preferential incorporation of $\mathrm{Fe}^{2+}$ in minerals (Kelley and Cottrell, 2012) and fluids (Bell

156 and Simon, 2011) and preferential degassing of $\mathrm{H}_{2}$ relative to $\mathrm{O}_{2}$ during $\mathrm{H}_{2} \mathrm{O}$

157 disproportionation (Mathez, 1984). Although primitive arc magmas are usually

158 considered to be oxidized $\left(f \mathrm{O}_{2} \geq \mathrm{FMQ}+2\right.$; Mungall, 2002), the deep mafic magmas

159 feeding Merapi were sufficiently reduced, with $f \mathrm{O}_{2}$ at or near FMQ (Jugo, 2009), to

160 exsolve an immiscible sulfide melt (Nadeau et al., 2010) and an aqueous fluid that 
Publisher: GSA

Journal: GEOL: Geology

DOI:10.1130/G37262.1

161 ultimately precipitated sulfides (Fig. 2b). Such immiscible sulfide melt inclusions also

162 have been observed at other arc volcanoes and in porphyry $\mathrm{Cu}$ deposits (Larocque et al.,

163 2000), suggesting that deep mafic feeders commonly may be less oxidized than shallower

164 porphyry stocks.

165 Variations in the degree of oxidation of magmas and fluids have an important

166 impact on metal transport characteristics. Highly oxidized magmas lack sulfides that

167 could scavenge chalcophile and siderophile metals from magmatic-hydrothermal

168 systems. In contrast, S-rich, reduced magmas may exsolve chalcophile element-rich

169 immiscible sulfide melts that, in turn, can be subsequently dissolved in magmatic

170 hydrothermal fluids (Nadeau et al., 2010; Mungall et al., 2015). High oxidation states of

171 hydrothermal fluids lead to low $\mathrm{H}_{2} \mathrm{~S} / \mathrm{SO}_{2}$ ratios, inhibiting the solubility of metals that are

172 dissolved dominantly as bisulfide complexes (Zezin et al., 2011) but enhancing the

173 capacity of the melt to transport sulfur as $\mathrm{SO}_{4}{ }^{2-}(\mathrm{Jugo}, 2009)$.

\section{Metallogenesis of Porphyry-Type Deposits}

175 We propose that porphyry-epithermal systems evolve by cycling through periods

176 of volcanic quiescent degassing dominated by fractional crystallization and volatile

177 exsolution, and periods of explosive activity triggered by injection of mafic magmas (Fig.

178 4). According to this hypothesis, quiescently devolatilizing magmas evolve under

179 lithostatic pressure gradients to relatively shallow depths (the critical depth is $5 \mathrm{~km}$ in the

$180 \mathrm{H}_{2} \mathrm{O}-\mathrm{NaCl}$ system; Driesner and Heinrich, 2007). Incompatible metals such as Au, Mo,

181 REE, HFSE and LILE are gradually enriched in the magmas and fluids and deposited in

182 these relatively oxidizing environments. Injections of less oxidized mafic magmas open

183 up the systems and abruptly decrease the confining pressures to values closer to the 


\section{Publisher: GSA \\ Journal: GEOL: Geology \\ DOI:10.1130/G37262.1}

184 hydrostatic gradient, thereby displacing the critical depth to deeper levels (15 $\mathrm{km}$ in the

$185 \mathrm{H}_{2} \mathrm{O}-\mathrm{NaCl}$ system; Driesner and Heinrich, 2007). Regional tectonic earthquakes, such as

186 that which occurred near Merapi during the eruption of 2006, also may enhance the

187 pressure regime transition by opening the systems. Although experimental studies in the

$188 \mathrm{H}_{2} \mathrm{O}-\mathrm{NaCl}$ system suggest a critical depth of $15 \mathrm{~km}$ under a hydrostatic pressure gradient,

189 a study of rock rheology suggests that a hydrostatic regime would be difficult to maintain

190 at depths greater than $\sim 5-10 \mathrm{~km}$ (Sibson, 1992). Hence the pressure regime at this stage

191 may lie between lithostatic and hydrostatic. Upon depressurization, sulfur partitions

192 preferentially into the vapor which rises and expands, whereas chlorine remains in the

193 brine that ponds beneath the volcano.

194 After the injection of mafic magma, $\mathrm{Cu}$ bonds with $\mathrm{S}$ to precipitate as a sulfide

195 mineral under the combined effects of decompression and expansion of the hydrated

196 metal complexes. The precipitation of $\mathrm{Zn}$ and $\mathrm{Pb}$, which are also enriched in the

197 hydrothermal system after rock failure and decompression, is not as abrupt as that of $\mathrm{Cu}$

198 (Fig. 3b) as these metals form stronger bonds with $\mathrm{Cl}$. Their precipitation in sulfide

199 minerals is thus delayed relative to $\mathrm{Cu}$. After explosive eruptions which typically last

200 several months and contribute to fracturing and brecciating rocks at progressively greater

201 depths, the magmas evolve by fractional crystallization, gradually becoming more

202 oxidized and enriched in incompatible elements. The hydrothermal system seals itself by

203 precipitation of minerals along fractures and in breccias under the weight of the rock

204 column, with pressure returning to lithostatic levels. The ability of the fluid to dissolve

205 metals gradually increases until the next explosive eruption (or rock failure at depth),

206 typically a few years later. 
Publisher: GSA

Journal: GEOL: Geology

DOI:10.1130/G37262.1

Although economic mineralization is usually thought to postdate volcanism

209 (Williams-Jones and Heinrich, 2005), numerous ore deposits have been shown to be

210 genetically associated with volcanism (Hattori and Keith, 2001). In this paper, we have

211 related variations in the composition of volcanic vapors from Merapi volcano to different

212 stages of its eruptive cycle and compared these compositions to those of volcanic vapors

213 from other subduction zone volcanoes and porphyry-hosted fluid inclusions. These data

214 provide the first convincing evidence that injections of mafic magma (which commonly

215 coincide with explosive volcanic eruptions) are followed by decompression of the

216 magmatic hydrothermal system, inducing fluid phase separation, rapid cooling and the

217 deposition of porphyry and epithermal ores. In so doing they demonstrate that

218 decompression is the principal control on mineralization, and that pressure in the systems

219 transforms abruptly from lithostatic during quiescence to hydrostatic during and

220 immediately after an explosive eruption (rock failure at depth). During quiescence,

221 magmatic-hydrothermal systems evolve through crystallization and devolatilization,

222 gradually becoming oxidized and enriched in gold and other incompatible metals. Upon

223 injection of mafic magmas, they are depressurized, supercritical fluids unmix into vapor

224 and brine, temperature drops, base metal sulfides precipitate at depth and volcanoes erupt

225 explosively.

\section{ACKNOWLEDGMENTS}

227 This research was made possible by NSERC Discovery grants to AEWJ and JS,

228 and an NSERC PhD scholarship to ON. We thank F. Gaillard and two anonymous

229 reviewers for their constructive comments. 
Publisher: GSA

Journal: GEOL: Geology

DOI:10.1130/G37262.1

231 Bell, A.S. and Simon, A., 2011. Experimental evidence for the alteration of the $\mathrm{Fe}^{3+} /$

232

233

234

235

236

237

238

239

240

241

242

243

244

245

246

247

248

249

250

251

252

\section{REFERENCES CITED} $\sum F e$ of silicate melt caused by the degassing of chlorine-bearing aqueous volatiles. Geology, v. 39, p. 499-502, doi: 10.1130/G31828.1

Bodnar, R.J., Burnham, C.W., and Sterner, S.M., 1985, Synthetic fluid inclusions in natural quartz; III, Determination of phase equilibrium properties in the system $\mathrm{H}_{2} \mathrm{O}$ $\mathrm{NaCl}$ to 1000 degrees $\mathrm{C}$ and 1500 bars: Geochimica et Cosmochimica Acta, v. 49, p. 1861-1873, doi:10.1016/0016-7037(85)90081-X.

Camus, G., Gourgaud, A., Mossand-Berthommier, P. C., Vincent, P. M., 2000. Merapi (central Java, Indonesia); an outline of the structural and magmatological evolution, with a special emphasis to the major pyroclastic events. Journal of Volcanology and Geothermal Research, v. 100, p. 139-163, doi:10.1016/S0377-0273(00)00135-9

Driesner, T., and Heinrich, C.A., 2007, The system $\mathrm{H}_{2} \mathrm{O}-\mathrm{NaCl}$; Part I, Correlation formulae for phase relations in temperature-pressure-composition space from 0 to 1000 degrees $\mathrm{C}, 0$ to 5000 bar, and 0 to $1 \mathrm{X}_{\mathrm{NaCl}}$ : Geochimica et Cosmochimica Acta, v. 71, p. 4880-4901, doi:10.1016/j.gca.2006.01.033.

Eichelberger, J.C., 1980, Vesiculation of mafic magma during replenishment of silicic magma reservoirs: Nature, v. 288, p. 446-450, doi:10.1038/288446a0.

Hattori, K.H., and Keith, J.D., 2001, Contribution of mafic melt to porphyry copper mineralization; evidence from Mount Pinatubo, Philippines, and Bingham Canyon, Utah, USA: Mineralium Deposita, v. 36, p. 799-806, doi:10.1007/s001260100209.

Jugo, P.J., 2009, Sulfur content at sulfide saturation in oxidized magmas: Geology, v. 37, p. 415-418, doi:10.1130/G25527A.1. 
Publisher: GSA

Journal: GEOL: Geology

DOI:10.1130/G37262.1

253 Kelley, K.A., and Cottrell, E., 2012, The influence of magmatic differentiation on the

254 oxidation state of Fe in a basaltic arc magma: Earth and Planetary Science Letters,

255 v. 329-330, p. 109-121, doi:10.1016/j.epsl.2012.02.010.

256 Larocque, A.C.L., Stimac, J.A., Keith, J.D., and Huminicki, M.A.E., 2000, Evidence for 257 open-system behavior in immiscible Fe-S-O liquids in silicate magmas; implications

258 for contributions of metals and sulfur to ore-forming fields: Canadian Mineralogist,

$259 \quad$ v. 38, p. 1233-1249, doi:10.2113/gscanmin.38.5.1233.

260 Lerchbaumer, L., and Audétat, A., 2012, High Cu concentrations in vapor-type fluid

261 inclusions: An artifact?: Geochimica et Cosmochimica Acta, v. 88, p. 255-274,

262 doi:10.1016/j.gca.2012.04.033.

263 Mathez, E.A., 1984, Influence of degassing on oxidation states of basaltic magmas:

264 Nature, v. 310, p. 371-375, doi:10.1038/310371a0.

265 Maughan, D.T., Keith, J.D., Christiansen, E.H., Pulsipher, T., Hattori, K., and Evans, N.,

2662002 , Contributions from mafic alkaline magmas to the Bingham porphyry $\mathrm{Cu}-\mathrm{Au}-$

267 Mo deposit, Utah, USA: Mineralium Deposita, v. 37, p. 14-37, doi:10.1007/s00126-

$268 \quad 001-0228-5$.

269 McDonough, W.F., and Sun, S., 1995, The composition of the Earth: Chemical Geology,

270 v. 120, p. 223-253, doi:10.1016/0009-2541(94)00140-4.

271 Migdisov, A., Bychkov, A.Y., Williams-Jones, A.E., and van Hinsberg, V.J., 2014, A

272 predictive model for the transport of copper by HCl-bearing water vapour in ore-

273 forming magmatic-hydrothermal systems; implications for copper porphyry ore

274 formation: Geochimica et Cosmochimica Acta, v. 129, p. 33-53,

$275 \quad$ doi:10.1016/j.gca.2013.12.024

Page 12 of 16 
Publisher: GSA

Journal: GEOL: Geology

DOI:10.1130/G37262.1

276 Mungall, J.E., 2002. Roasting the mantle; slab melting and the genesis of major Au and

277 Au-rich Cu deposits. Geology, v. 30, p. 915-918, doi: 10.1130/0091-

Mungall, J.E., Brenan, J.M., Godel, B., Barnes, J.J., and Gaillard, F., 2015, Transport of metals and sulphur in magmas by flotation of sulphide melt on vapour bubbles: Nature Geoscience, v. 8, p. 216-219, doi:10.1038/ngeo2373.

Nadeau, O., Williams-Jones, A.E., and Stix, J., 2010, Sulfide magma as a source of metals in arc-related magmatic hydrothermal ore fluids: Nature Geoscience, v. 3, p. 501-505, doi:10.1038/ngeo899.

Nadeau, O., Williams-Jones, A.E., and Stix, J., 2013, Magmatic-Hydrothermal Evolution and Devolatilization Beneath Merapi Volcano, Indonesia: Journal of Volcanology and Geothermal Research, v. 261, p. 50-68, doi:10.1016/j.jvolgeores.2013.04.006.

Newhall, C.G., Bronto, S., Alloway, B.V., Banks, N.G., Bahar, I., del Marmol, M.A., Hadisantono, R.D., Holcomb, R.T., McGeehin, J.P., Miksic, J.N., Rubin, Meyer, Sayudi, D.S., Sukhyar, R., Andreastuti, S.D., Tilling, R.I., Torley, R., Trimble, D.A.,

297 Sillitoe, R.H., 2010, Porphyry copper systems: Economic Geology and the Bulletin of the 298 Society of Economic Geologists, v. 105, p. 3-41, doi:10.2113/gsecongeo.105.1.3. 
Publisher: GSA

Journal: GEOL: Geology

DOI:10.1130/G37262.1

299 Simon, A.C., and Ripley, E.M., 2011, The role of magmatic sulfur in the formation of ore

300 deposits: Reviews in Mineralogy and Geochemistry, v. 73, p. 513-578,

$301 \quad$ doi:10.2138/rmg.2011.73.16.

302 Webster, J.D., and Mandeville, C.W., 2007, Fluid immiscibility in volcanic

303 environments: Reviews in Mineralogy and Geochemistry, v. 65, p. 313-362,

304 doi:10.2138/rmg.2007.65.10.

305 Williams-Jones, A.E., and Heinrich, C.A., 2005, Vapor transport of metals and the

306 formation of magmatic-hydrothermal ore deposits: Economic Geology and the

307 Bulletin of the Society of Economic Geologists, v. 100, p. 1287-1312,

308 doi:10.2113/gsecongeo.100.7.1287.

309 Zajacz, Z., Halter, W.E., Pettke, T., and Guillong, M., 2008, Determination of fluid/melt

310 partition coefficients by LA-ICPMS analysis of co-existing fluid and silicate melt

311 inclusions; controls on element partitioning: Geochimica et Cosmochimica Acta,

312 v. 72, p. 2169-2197, doi:10.1016/j.gca.2008.01.034.

313 Zezin, D.Y., Migdisov, A.A., and Williams-Jones, A.E., 2011, The solubility of gold in

$314 \mathrm{H}_{2} \mathrm{O}-\mathrm{H}_{2} \mathrm{~S}$ vapour at elevated temperature and pressure: Geochimica et Cosmochimica

$315 \quad$ Acta, v. 75, p. 5140-5153, doi:10.1016/j.gca.2011.06.027.

\section{FIGURE CAPTIONS}

319 Figure 1. Compositions of condensed vapors from Merapi in 2004-2006. Elements are

320 normalized to Na (a) and to chondrite (b) or MORB (c) (McDonough and Sun, 1995).

321 The gray envelopes represent all data from Merapi. 
Publisher: GSA

Journal: GEOL: Geology

DOI:10.1130/G37262.1

322

323 Figure 2. Mineralogy of volcanic vapor sublimates from Merapi in 2004-2006.

324

325 Figure 3. Compositions of volcanic vapor condensates (a) and comparison of fluid

326 inclusion and vapor condensate compositions (b) from selected arc volcanoes and

327 porphyry deposits. See supplementary information for references.

328

329 Figure 4. Schematic model showing the evolution of porphyry systems based on Merapi

330 volcano, Indonesia.

331

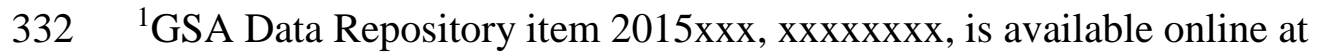

333 www.geosociety.org/pubs/ft2015.htm, or on request from editing@ geosociety.org or

334 Documents Secretary, GSA, P.O. Box 9140, Boulder, CO 80301, USA.

335

336

337

338

339

340

341

342

343

344

345

346

347

348

349

TABLE 1. COMPOSITIONS OF CONDENSED VOLCANIC VAPORS FROM MERAPI IN 2004-2006.

\begin{tabular}{ccccccccccccccccc}
\hline \hline Year & Sample & Na & S & Cl & Ti & Cu & Zn & Sr & Y & Zr & Mo & Ba & La & Ce & Pr & Nd \\
\hline 2004 & M4W1 & 3.43 & 263 & 3030 & 0.40 & & 0.150 & 0.075 & 0.0039 & 0.0121 & 0.0200 & 0.281 & 0.0032 & 0.00718 & 0.00084 & 0.00365 \\
2004 & M4W3 & 0.60 & 520 & 893 & 0.21 & 0.003 & 0.060 & 0.015 & 0.0007 & 0.0048 & 0.0040 & 0.11 & 0.00078 & 0.0014 & 0.00015 & 0.00065 \\
2006 & M6W1 & 2.31 & 6733 & 4849 & 0.05 & 0.161 & 0.420 & 0.020 & 0.0004 & 0.0222 & & 0.0342 & 0.00023 & 0.001862 & 0.000177 & 0.00072 \\
2006 & M6W2 & 1.21 & 10579 & 7193 & 0.05 & 0.279 & 0.150 & 0.019 & 0.0005 & 0.0114 & 0.0006 & 0.0555 & 0.000928 & 0.001798 & 0.000221 & 0.000813
\end{tabular}


Publisher: GSA

Journal: GEOL: Geology

DOI:10.1130/G37262.1

\begin{tabular}{|c|c|c|c|c|c|c|c|c|c|c|c|c|c|c|c|c|}
\hline Year & Sample & Sm & Eu & Gd & Tb & Dy & Ho & $\mathrm{Er}$ & $\mathrm{Tm}$ & $\mathrm{Yb}$ & Lu & Hf & $\mathrm{Ta}$ & $\mathrm{Au}$ & $\mathrm{Pb}$ & $\mathbf{U}$ \\
\hline 2004 & M4W1 & 0.00089 & 0.00024 & 0.00095 & 0.00014 & 0.00073 & 0.00015 & 0.00041 & 0.00006 & 0.00041 & 0.00006 & 0.00031 & 0.00035 & 0.00060 & 1.41000 & 0.00034 \\
\hline 2004 & M4W3 & 0.00015 & 0.00006 & 0.00013 & 0.00003 & 0.00011 & 0.00003 & 0.00007 & & 0.00008 & 0.00001 & 0.00012 & 0.00011 & 0.00020 & 0.07000 & 0.00009 \\
\hline 2006 & M6W1 & 0.00019 & 0.00003 & 0.00009 & 0.00001 & 0.00009 & 0.00002 & 0.00008 & 0.00000 & 0.00005 & & 0.00049 & 0.00003 & & 8.53000 & 0.00006 \\
\hline 2006 & M6W2 & 0.00020 & 0.00005 & 0.00014 & 0.00007 & 0.00013 & 0.00002 & 0.00009 & 0.00002 & 0.00005 & 0.00001 & 0.00028 & 0.00003 & 0.00002 & 8.01000 & 0.00008 \\
\hline
\end{tabular}
350 

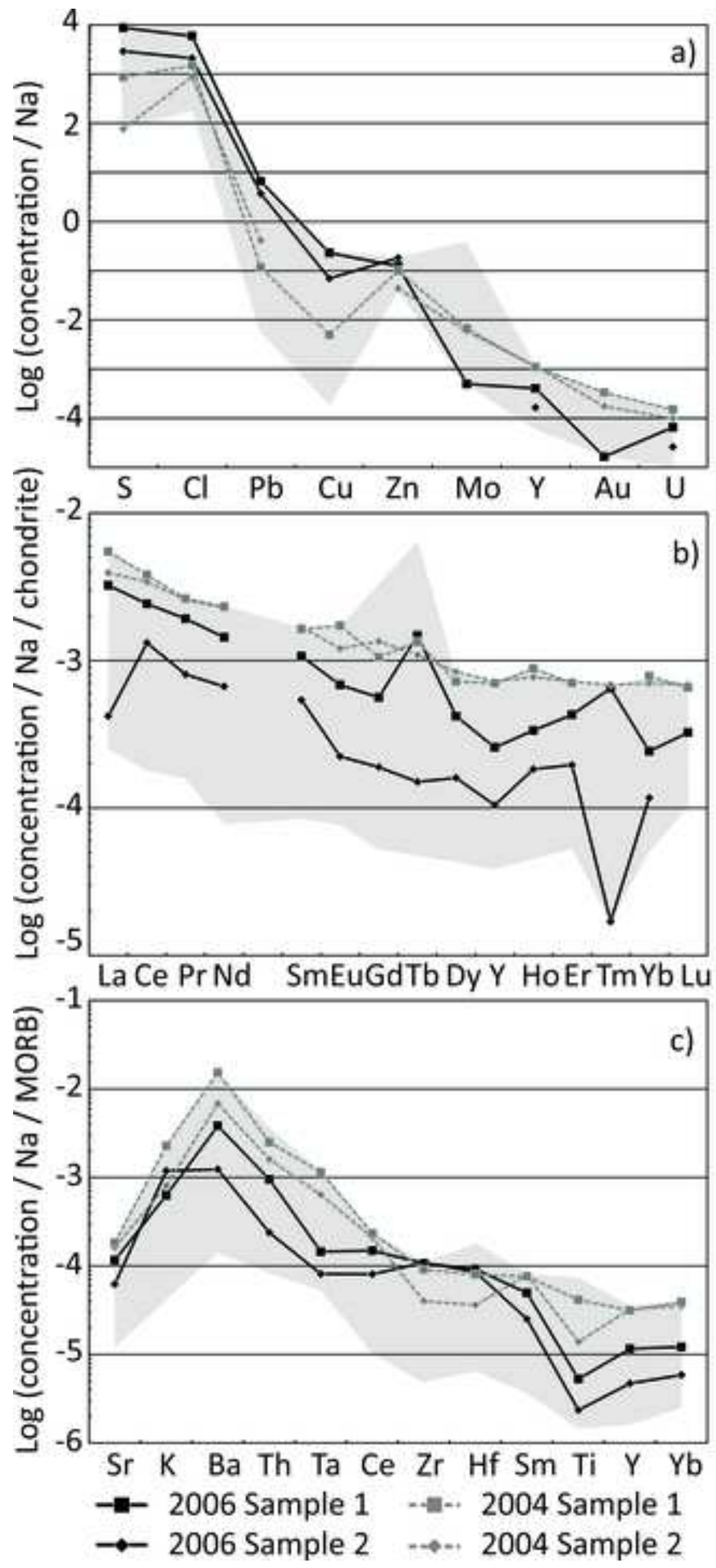

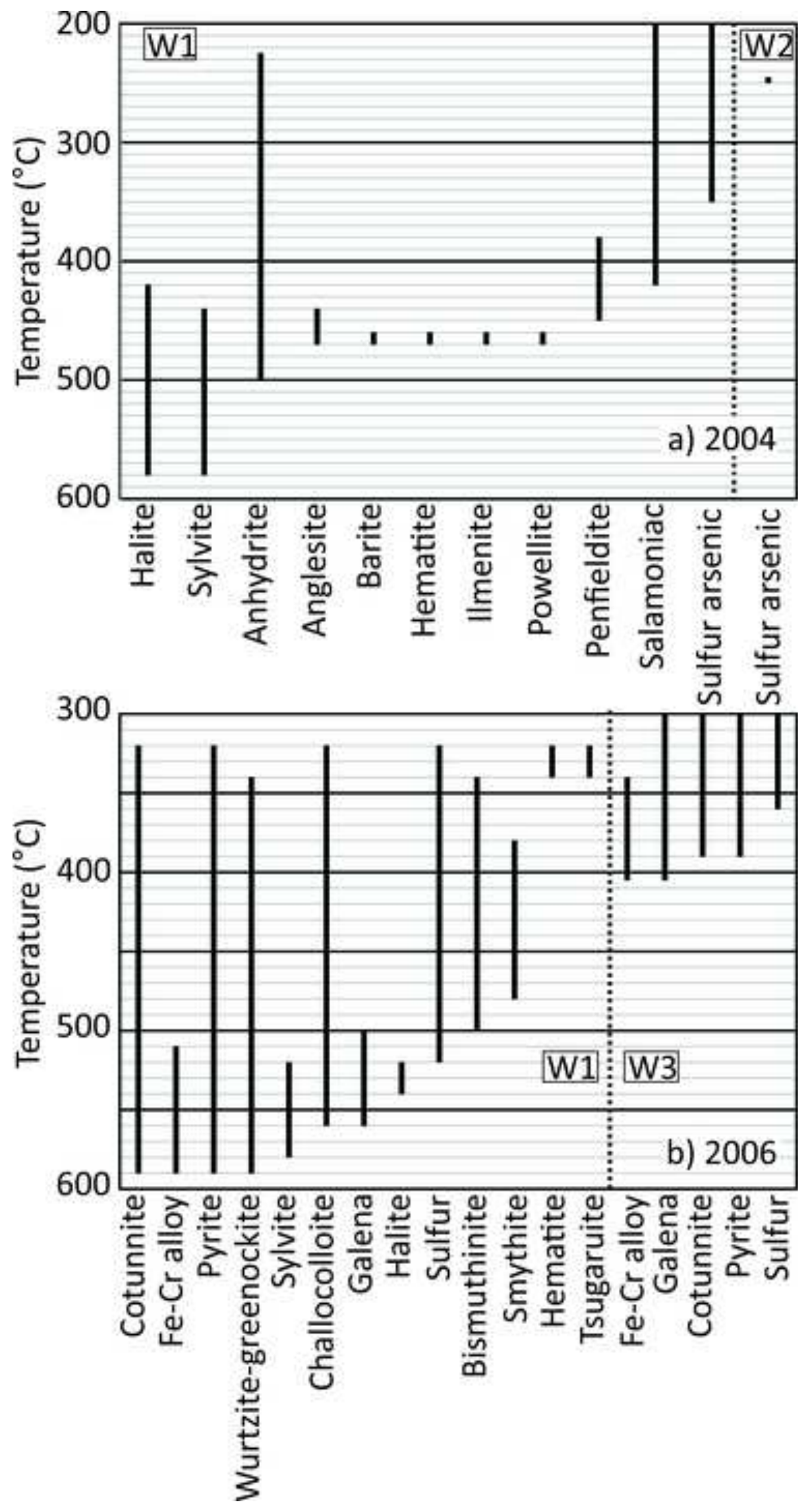

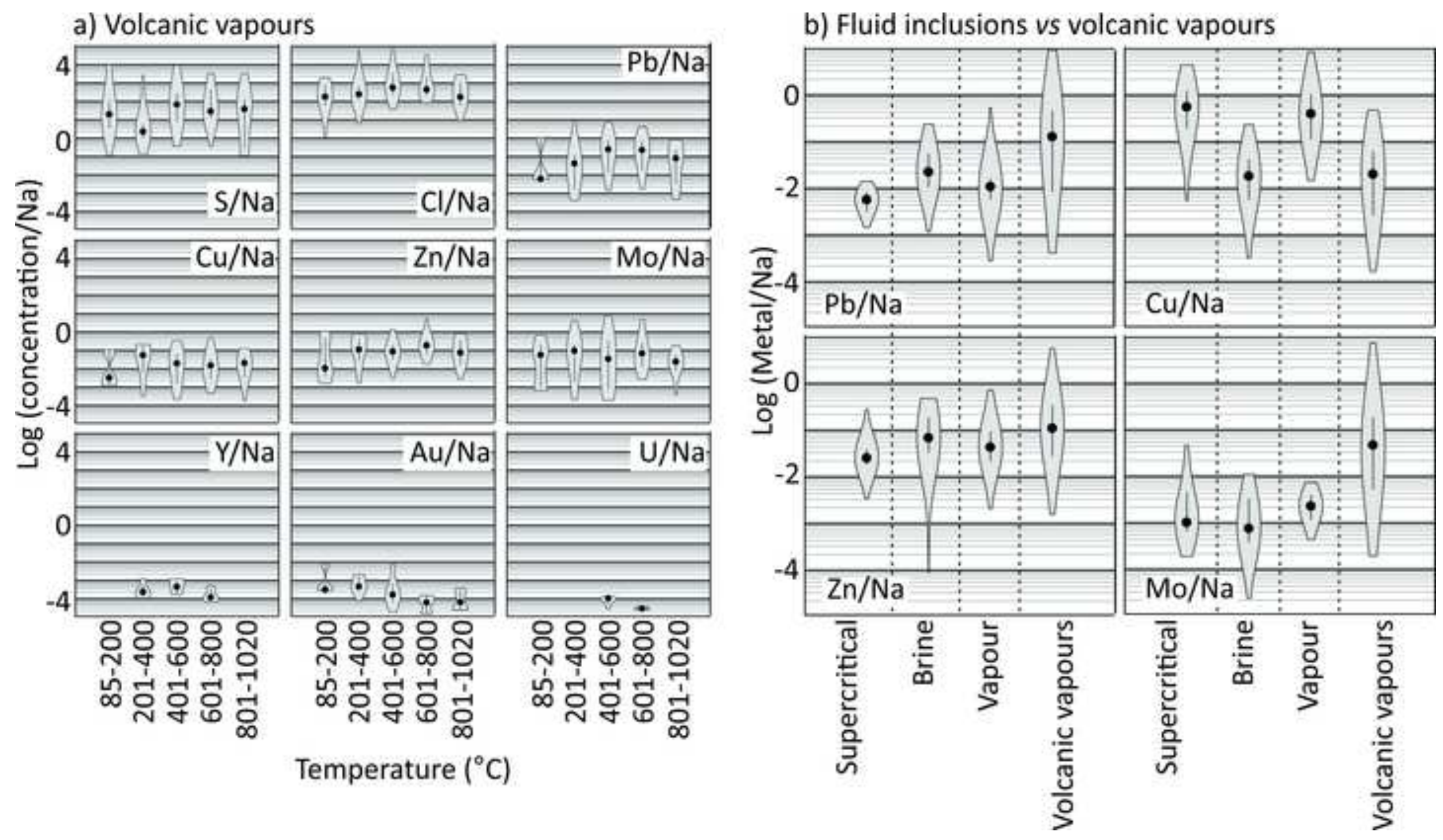


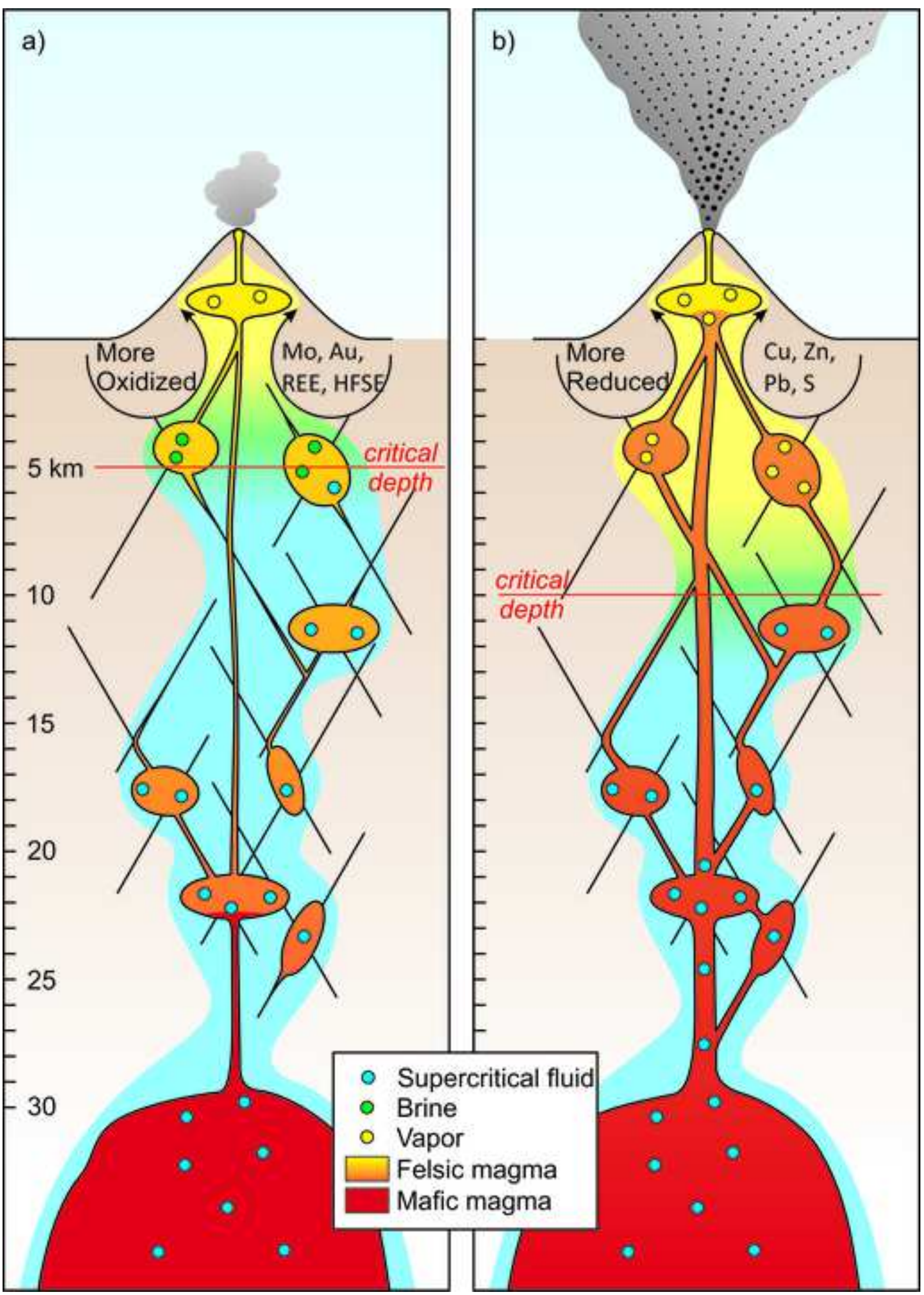


Table 1

\begin{tabular}{|c|c|c|c|c|c|c|c|c|c|c|c|c|c|c|c|c|}
\hline Year & Sample & $\mathrm{Na}$ & $\mathbf{s}$ & $\mathrm{Cl}$ & $\mathrm{Ti}$ & $\mathrm{Cu}$ & $\mathrm{Zn}$ & $\mathrm{Sr}$ & $\mathbf{Y}$ & $\mathrm{Zr}$ & Mo & $\mathrm{Ba}$ & La & Ce & $\mathrm{Pr}$ & Nd \\
\hline 2004 & M4W1 & 3.43 & 263 & 3030 & 0.40 & & 0.150 & 0.075 & 0.0039 & 0.0121 & 0.0200 & 0.281 & 0.0032 & 0.00718 & 0.00084 & 0.00365 \\
\hline 2004 & M4W3 & 0.60 & 520 & 893 & 0.21 & 0.003 & 0.060 & 0.015 & 0.0007 & 0.0048 & 0.0040 & 0.11 & 0.00078 & 0.0014 & 0.00015 & 0.00065 \\
\hline 2006 & M6W1 & 2.31 & 6733 & 4849 & 0.05 & 0.161 & 0.420 & 0.020 & 0.0004 & 0.0222 & & 0.0342 & 0.00023 & 0.001862 & 0.000177 & 0.00072 \\
\hline 2006 & M6W2 & 1.21 & 10579 & 7193 & 0.05 & 0.279 & 0.150 & 0.019 & 0.0005 & 0.0114 & 0.0006 & 0.0555 & 0.000928 & 0.001798 & 0.000221 & 0.000813 \\
\hline Year & Sample & Sm & Eu & Gd & Tb & Dy & Ho & $\mathrm{Er}$ & $\mathrm{Tm}$ & $\mathrm{Yb}$ & Lu & $\mathrm{Hf}$ & Ta & $\mathrm{Au}$ & $\mathrm{Pb}$ & u \\
\hline 2004 & M4W1 & 0.00089 & 0.00024 & 0.00095 & 0.00014 & 0.00073 & 0.00015 & 0.00041 & 0.00006 & 0.00041 & 0.00006 & 0.00031 & 0.00035 & 0.00060 & 1.41000 & 0.00034 \\
\hline 2004 & M4W3 & 0.00015 & 0.00006 & 0.00013 & 0.00003 & 0.00011 & 0.00003 & 0.00007 & & 0.00008 & 0.00001 & 0.00012 & 0.00011 & 0.00020 & 0.07000 & 0.00009 \\
\hline 2006 & M6W1 & 0.00019 & 0.00003 & 0.00009 & 0.00001 & 0.00009 & 0.00002 & 0.00008 & 0.00000 & 0.00005 & & 0.00049 & 0.00003 & & 8.53000 & 0.00006 \\
\hline 2006 & M6W2 & 0.00020 & 0.00005 & 0.00014 & 0.00007 & 0.00013 & 0.00002 & 0.00009 & 0.00002 & 0.00005 & 0.00001 & 0.00028 & 0.00003 & 0.00002 & 8.01000 & 0.00008 \\
\hline
\end{tabular}


Volcanic Processes and the Genesis of Porphyry and Epithermal Ore Deposits

Olivier Nadeau ${ }^{1}$, John Stix ${ }^{2}$ and Anthony E. Williams-Jones ${ }^{2}$

${ }^{1}$ Department of Earth and Environmental Sciences, University of Ottawa, Ottawa (Ontario), K1N 6N5, Canada

${ }^{2}$ Department of Earth and Planetary Sciences, McGill University, Montreal (Quebec), H3A OE8, Canada

\section{Supplementary Information}

\section{Geological Context}

Merapi volcano was most active within the last 40,000 years (Camus et al., 2000). Since the beginning of the 20th century, Merapi has alternated between periods of quiescent degassing and lava dome growth and occasional collapse, typically lasting a few years, and periods of explosive activity, with St-Vincent type explosions, pyroclastic flows and surges, typically lasting several months. From September 2002 to March 2006, the volcano was in a phase of quiescent degassing. From March to July 2006, it went through a phase of explosive activity, with its plume reaching an altitude of $3.7 \mathrm{~km}$ and erupting about $1.07 \times 10^{10} \mathrm{~kg}$ of rock (Ratdomopurbo et al., 2013). On May 27th 2006, a magnitude 6.3 earthquake occurred about $50 \mathrm{~km} \mathrm{SW}$ of Merapi at a depth of about $10 \mathrm{~km}$, resulting in a three-fold increase of volcanic activity (Global Volcanism Program of the National Museum of Natural History - Smithsonian Institution (GVP); United States Geological Survey, consulted online in June 2015). From July 2006 and until October 2010, it went back to a phase of quiescence. In 2010, the volcano had its greatest eruption since 1872. From October to November 2010, Merapi erupted about $3.1 \times 10^{11} \mathrm{~kg}$ of rock and degassed about $0.44 \times 10^{9} \mathrm{~kg}$ of $\mathrm{SO}_{2}$ (GVP; Surono et al., 2012). Although the initial explosion occurred 19 hours after a magnitude 7.7 earthquake $1200 \mathrm{~km} \mathrm{NW}$ of Merapi, any links between this seismic event and the major eruption of 2010 are difficult to prove. Volcanic vapours at Merapi emanate from distinct fumarole fields. Gendol was the highest temperature fumarole field, with temperature reaching up to $900^{\circ} \mathrm{C}$ (Le Guern, 1979), until it was destroyed by the eruption in 2006. Woro was a lower temperature fumarole field, reaching up to $710^{\circ} \mathrm{C}$ (Le Guern et al., 1982), until it was destroyed by the 2010 eruption. In this paper we used only the volcanic vapour data from Woro as they were the only dataset that could be compared between 2004 and 2006 and because vapours from distinct fumarole fields cannot be compared directly.

\section{Supplementary Methods}

\section{Condensates of volcanic vapor}

Volcanic vapours were sampled by inserting meter-long fused silica tubes into fumaroles and connecting the quartz tubes to condensers filled with ice and pumping the vapour slowly through the condenser using a hand-held pump. The liquid that collected in the condensor was stored in Teflon bottles and analyzed at Actlabs Inc., Canada, by a combination of inductively coupled plasma mass spectrometry (ICP-MS), ICP optical emission spectrometry (OES), neutron activation (INAA) and ion chromatography. 
The sampling of vapor condensates was complemented by inserting meter-long, fused silica tubes into the fumaroles immediately after the condensates had been collected and waiting until sufficient solid had precipitated on the inner walls of the tubes (Le Guern et al., 1982). In 2004, tubes were inserted for periods varying between four and six days. In 2006, tubes were in place for a period of 22 days. The sampling was done during the dry season to avoid dissolution and redistribution of sublimates by rain. Temperatures were measured along the tube centerlines at $10 \mathrm{~cm}$ intervals using a meter-long thermocouple and the tubes were subsequently cut into sections representing increments of 10 to $20^{\circ} \mathrm{C}$. The sublimates were scraped off and a fraction of each sublimate was mounted on a glass slide and polished. As several of the sublimate phases are water soluble (e.g., halite and sylvite), the polishing agent (aluminium oxide or diamond powder) was suspended in alcohol rather than water. The phases in the polished sections were analysed chemically using a JEOL JXA-8900L electron microprobe (EMPA) at McGill University. A second fraction of sublimate was scanned using a Siemens D500 X-ray diffractometer equipped with a Co tube and a Si detector at the Université du Québec à Montréal. The diffraction patterns were analyzed using Jade software at McGill University for identification of major phases.

\section{Supplementary Tables}

Table S1. Mineralogy and temperature distribution of of volcanic vapour sublimates collected from Merapi volcano in 2004-2006.

Table S2. Compilation of volcanic vapour condensates

A total of 282 samples of vapour condensates from subduction zone stratovolcanoes with trace element concentrations were compiled from the literature (Fig. 2). Data were taken from Arenal, Costa Rica (Stoiber and Rose, 1970), Augustine, Alaska (Symonds et al., 1990), Cerro Negro, Nicaragua (Gemmel, 1987; Stoiber and Rose, 1970), Colima, Mexico (Taran et al., 2001), Fuego, Guatemala (Stoiber and Rose, 1970), Izalco, El Salvador (Stoiber and Rose, 1970), Kawa Ijen, Indonesia (Berlo et al., 2014), Kudryavy, Russia (Wahrenberger et al., 2002; Taran et al., 1995), Masaya, Nicaragua (Gemmel, 1987), Merapi, Indonesia (this research; Symonds et al., 1987), Momotombo, Nicaragua (Gemmel, 1987), Mutnovsky, Kamchatka (Zelensky et al., 2005), New Tolbachik, Kamchatka (Menyailov and Nikitina, 1980), Pacaya, Guatemala (Stoiber and Rose, 1970), Poas, Costa Rica (Gemmel, 1987), Santiagito, Guatemala (Stoiber and Rose, 1970), Satsuma Iwojima, Japan (Hedenquist et al., 1994), Showa Shinzan, Japan (Oana, 1962; Mizutani, 1970; Symonds et al., 1996) and St-Helens, USA (Bernard et al., 1990). The concentrations of S, $\mathrm{Cl}, \mathrm{Pb}, \mathrm{Cu}, \mathrm{Zn}, \mathrm{Mo}, \mathrm{Y}, \mathrm{Au}$ and $\mathrm{U}$ were normalized to $\mathrm{Na}$ to neutralise the effect of dilution by $\mathrm{H}_{2} \mathrm{O}$. The concentration of these elements did not show any correlation with the silica content nor with the alkalinity of the associated volcanic rocks. Conversely, a correlation was observed between their composition and temperature. The samples were thus separated into five temperature groups, i.e., 85 $200^{\circ} \mathrm{C}(\mathrm{n}=23), 201-400^{\circ} \mathrm{C}(\mathrm{n}=109), 401-600^{\circ} \mathrm{C}(\mathrm{n}=55), 601-800^{\circ} \mathrm{C}(\mathrm{n}=44)$ and $801-1020^{\circ} \mathrm{C}(\mathrm{n}=19)$. These results are reported in "violin plots", using NCSS statistical software, showing the median (black dot), the interquartile range (central vertical line extending from the 25th to 75th percentile) and the total distribution (gray envelopes; width representing the amount of data).

Most of the violin plots show normal distributions, with medians near the centres of the interquartile bars and the latter approximately in the middle of the total distribution, except for some plots of the low temperature group with abnormal distributions, due to limited data. Uranium, $Y$, and Au to a lesser extent, also have limited data and show a limited temperature distribution and inconsistent statistical values. Sulphur and $\mathrm{Cl}$ have the highest concentrations of the elements in the volcanic vapour 
condensates other than $\mathrm{H}$ and $\mathrm{O}$. Concentrations of $\mathrm{S}$ range from $2 \mathrm{ppm}$ to $2.7 \mathrm{wt} . \%$ and $\mathrm{Cl}$ from $10 \mathrm{ppm}$ to $6.6 \mathrm{wt} . \%$, values which are significantly higher than those of the base metals ( $\mathrm{Pb}-\mathrm{Cu}-\mathrm{Zn}-\mathrm{Mo}$ ), which vary between $0.01 \mathrm{ppb}$ and $21.9 \mathrm{ppm}$, and trace metals (REE, $\mathrm{Au}, \mathrm{U}$ ) which vary between $0.001 \mathrm{ppb}$ and $0.22 \mathrm{ppm}$ (Gemmel, 1987).

The temperature distribution of the volatile and metallic elements results in convex-upward patterns with maxima at intermediate values (usually around $400-800^{\circ} \mathrm{C}$ ) and lower values at lower $\left(85-400^{\circ} \mathrm{C}\right.$ ) and higher $\left(800-1020^{\circ} \mathrm{C}\right)$ temperatures. Copper has a maximum concentration in vapours at $200-400^{\circ} \mathrm{C}$, whereas $\mathrm{Mo}$ is most concentrated in vapours at $200-400^{\circ} \mathrm{C}$ and $600-800^{\circ} \mathrm{C}$. Although very little data is available for $\mathrm{Y}, \mathrm{Au}$ and $\mathrm{U}, \mathrm{Y}$ appears more concentrated in vapours of medium temperature $\left(400-600^{\circ} \mathrm{C}\right)$, whereas Au appears to be preferentially concentrated in vapours of lower temperature, $200-400^{\circ} \mathrm{C}$.

Table S3. Compilation of fluid inclusion data

A total of 292 analyses of fluid inclusions from seven porphyry $\mathrm{Cu} \pm \mathrm{Mo} \pm \mathrm{Au}$ deposits with trace element concentrations and physical phase descriptions (supercritical fluid, brine or vapour inclusions) were compiled from the literature (Fig. 4). The data are from Bajo de la Alumbrera Cu-Au porphyry, Chile (Seo et al., 2009; Ulrich et al, 2001), Bingham Cu-Au-Mo porphyry, USA (Landtwing et al., 2005; Seo et al., 2009), Butte Cu-Mo porphyry, USA (Rusk et al., 2004), El Teniente Cu-Mo porphyry, Chile (Klemm et al., 2007), Famatina Cu-Au porphyry-epithermal, Argentina (Pudack et al., 2009), Rosia-Poieni Cu-Au porphyry, Romania (Kouzmanov et al., 2010) and Santa Rita Cu (Mo) porphyry, New Mexico (Audétat et al., 2008). Only $\mathrm{Pb}, \mathrm{Cu}, \mathrm{Zn}$ and $\mathrm{Mo}$ are reported here because $\mathrm{S}, \mathrm{Cl}, \mathrm{Au}, \mathrm{REE}, \mathrm{Au}, \mathrm{U}$ and other elements were almost never reported. The concentrations of $\mathrm{Pb}, \mathrm{Cu}, \mathrm{Zn}$ and $\mathrm{Mo}$ were normalized to $\mathrm{Na}$ to neutralise the effect of dilution by $\mathrm{H}_{2} \mathrm{O}$ and to enable comparison between volcanic vapours and fluid inclusions. The $\mathrm{Pb} / \mathrm{Na}, \mathrm{Cu} / \mathrm{Na}, \mathrm{Zn} / \mathrm{Na}$ and $\mathrm{Mo} / \mathrm{Na}$ ratios are displayed as violin plots for supercritical fluid-, brine- and vapour inclusions and the ratios for volcanic vapours are displayed beside them.

The $\mathrm{Pb} / \mathrm{Na}$ ratio is smallest for supercritical fluid inclusions, averaging about 0.006 (note that the calculated averages and the medians shown on violin plots are not necessarily identical), and is progressively higher for vapour and brine inclusions. Volcanic vapours have a large range of $\mathrm{Pb} / \mathrm{Na}$ values that encompass all the fluid inclusion data and reach values much higher than the latter, averaging around 0.6 . The $\mathrm{Cu} / \mathrm{Na}$ ratios are similar for supercritical fluid and vapour inclusions, with values averaging around 0.8 . Brine and volcanic vapours also have similar ratios averaging of 0.03 and 0.05 , respectively. The distribution of $\mathrm{Zn} / \mathrm{Na}$ is very similar to that of $\mathrm{Pb} / \mathrm{Na}$; values are smallest for supercritical fluid inclusions, averaging around 0.035 , and are gradually higher in vapour and brine inclusions. The $\mathrm{Zn} / \mathrm{Na}$ ratio reaches a maximum average value of about 0.26 in volcanic vapours, where it also has the greatest range, again encompassing that of most fluid inclusions. Finally, Mo/Na ratios show the highest values (average 0.4 ) and the greatest variations in volcanic vapors like for $\mathrm{Pb} / \mathrm{Na}$ and $\mathrm{Zn} / \mathrm{Na}$. Vapour, supercritical fluid and brine inclusions have gradually lower Mo/Na ratios ranging between 0.005 and 0.002 .

\section{Mass balance calculations}

An actively forming porphyry system of intermediate size associated with an overlying volcano that erupts every 5 years would cycle 20,000 times during $100 \mathrm{ka}$. Assuming an intermediate-sized porphyry deposit containing $1 \mathrm{Gt}$ of $\mathrm{Cu}, 50 \mathrm{t}$ of $\mathrm{Cu}$ should be deposited during each cycle. If $50 \mathrm{wt}$ \% of the $\mathrm{Cu}$ present in the basalt is deposited in each cycle, $1.67 \mathrm{Gt}$ of basalt containing $60 \mathrm{ppm} \mathrm{Cu}$ (a normal value; see georoc database at georoc.mpch-mainz.gwdg.de/georoc) needs to be injected during each cycle. 
Given a density of $2800 \mathrm{~kg} / \mathrm{m}^{3}$, this represents a volume of $\sim 600$ million $\mathrm{m}^{3}$, which is a reasonable size for a mafic injection in the shallow part of subduction zone magma system (Pallister et al., 1992).

\section{Supplementary references}

Audetat, A., Pettke, T., Heinrich, C. A., Bodnar, R. J., 2008. Special paper; The composition of magmatichydrothermal fluids in barren and mineralized intrusions. Economic Geology 103, 877-908.

Berlo, K., van Hinsberg, V.J., Vigouroux, N., Gagnon, J.E., Williams-Jones, A.E., 2014. Sulfide breakdown controls metal signature in volcanic gas at Kawah Ijen volcano, Indonesia. Chemical Geology 371, 115-127.

Bernard, A., Symonds R.B., Rose W.I., 1990. Volatile transport and deposition of Mo, W and Re in high temperature magmatic fluids. Applied Geochemistry 5, 317-326.

Camus, G., Gourgaud, A., Mossand-Berthommier, P. C., Vincent, P. M., 2000. Merapi (central Java, Indonesia); an outline of the structural and magmatological evolution, with a special emphasis to the major pyroclastic events. Journal of Volcanology and Geothermal Research 100, 139-163.

Gemmell, J.B., 1987. Geochemistry of metallic trace elements in fumarolic condensates from Nicaraguan and Costa Rican volcanoes. Journal of Volcanology and Geothermal Research 33, 161-181.

Hedenquist, J.W., Aoki, M., Shinohara, H., 1994. Flux of volatiles and ore-forming metals from the magmatic-hydrothermal system of Satsuma Iwojima Volcano. Geology 22, 585-588.

Klemm, L.M., Pettke, T., Heinrich, C. A., Campos, E., 2007. Hydrothermal evolution of the El Teniente Deposit, Chile; porphyry Cu-Mo ore deposition from low-salinity magmatic fluids. Economic Geology 102, 1021-1045.

Kouzmanov, K., Pettke, T., Heinrich, C. A., Bodnar, R., Cline, J., 2010. Direct analysis of ore-precipitating fluids; combined IR microscopy and LA-ICP-MS study of fluid inclusions in opaque ore minerals. Economic Geology 105, 351-373.

Landtwing, M.R., Pettke, T., Halter, W. E., Heinrich, C. A., Redmond, P. B., Einaudi, M. T., Kunze, K., 2005. Copper deposition during quartz dissolution by cooling magmatic-hydrothermal fluids; the Bingham porphyry. Earth and Planetary Science Letters 235, 229-243.

Le Guern, F., Bicocchi P., Nohl A., Tazieff H., 1979. Volcanologie. - Analyse directe des gaz volcaniques. Comptes-Rendus de l'Académie des Sciences de Paris - Série D 288, 867-870.

Le Guern, F., Gerlach, T.M., Nohl, A., 1982. Field gas chromatograph analyses of gases from a glowing dome at Merapi Volcano, Java, Indonesia, 1977, 1978, 1979. Journal of Volcanology and Geothermal Research 14, 223-245.

Menyailov, I.A., Nikitina, L.P., 1980. Chemistry and metal contents of magmatic gases; the new Tolbachik volcanoes case (Kamchatka). Bulletin Volcanologique 43, 197-205.

Mizutani, Y., 1970. Copper and zinc in fumarolic gases of Showashimzan volcano, Hokkaido, Japan. Geochemical Journal 4, 87-91.

Oana, S., 1962. Volcanic gases and sublimates from Showashinzan. Bulletin of Volcanology 24, 49-57.

Pudack, C., Halter, W.E., Heinrich, C.A., Pettke, T., 2009. Evolution of magmatic vapor to gold-rich epithermal liquid; the porphyry to epithermal transition at Nevados de Famatina, northwest Argentina. Economic Geology 104, 449-477.

Ratdomopurbo, A., Beauducel, F., Subandriyo, J., Agung Nandaka, I.G.M., Newhall, C.G., Suharna, Sayudi, D.S., Suparwaka, H., Sunarta, 2013. Overview of the 2006 eruption of Mt. Merapi. Journal of Volcanology and Geothermal Research 261, 87-97.

Rusk, B.G., Reed, M.H., Dilles, J.H., Klemm, L.M., Heinrich, C.A., 2004. Compositions of magmatic hydrothermal fluids determined by LA-ICP-MS of fluid inclusions from the porphyry coppermolybdenum deposit at Butte, MT. Chemical Geology 210, 173-199. 
Seo, J.H., Guillong, M., Heinrich, C.A., 2009. The role of sulfur in the formation of magmatichydrothermal copper-gold deposits. Earth and Planetary Science Letters 282, 323-328.

Stoiber, R.E., Rose, W.I., 1970. The geochemistry of central american volcanic gas condensates. Geological Society of America Bulletin 81, 2891-2912.

Surono et al., 2012. The 2010 explosive eruption of Java's Merapi volcano-A '100-year' event. Journal of Volcanology and Geothermal Research 241-242, 121-135.

Symonds, R.B., Mizutani, Y., Briggs, P.H., 1996. Long-term geochemical surveillance of fumaroles at Showa-Shinzan Dome, Usu Volcano, Japan. Journal of Volcanology and Geothermal Research 73, 177-211.

Symonds, R.B., Rose W.I., Reed M.H., Lichte F.E., 1987. Volatilization, transport and sublimation of metallic and non-metallic elements in high temperature gases at Merapi Volcano, Indonesia. Geochimica et Cosmochimica Acta 51, 2083-2101.

Symonds, R.B., Rose, W.I., Gerlach, T.M., Briggs, P.H., Harmon, R.S., 1990. Evaluation of gases, condensates, and $\mathrm{SO}_{2}$ emissions from Augustine Volcano, Alaska; the degassing of a Cl-rich volcanic system. Bulletin of Volcanology 52, 355-374.

Taran, Y.A. et al., 2001. Chemistry and mineralogy of high-temperature gas discharges from Colima Volcano, Mexico; implications for magmatic gas-atmosphere interaction. Journal of Volcanology and Geothermal Research 108, 245-264.

Taran, Y.A., Hedenquist, J.W., Korzhinsky, M.A., Tkachenko, S.I., Shmulovich, K.I., 1995. Geochemistry of magmatic gases from Kudryavy Volcano, Iturup, Kuril Islands. Geochimica et Cosmochimica Acta 59, 1749-1761.

Ulrich, T., Günther, D., Heinrich, C.A., 2001. The evolution of a porphyry Cu-Au deposit, based on LA-ICPMS analysis of fluid inclusions; Bajo de la Alumbrera, Argentina. Economic Geology 96, 17431774.

Wahrenberger, C., Seward T.M., Dietrich V., 2002. Volatile trace-element transport in high-temperature gases from Kudryavy volcano (Iturup, Kurile Islands, Russia. In: Wood, R.H. editor, A tribute to A. Crerar. The Geochemical Society, 307-327.

Zelenski, M., Bortnikova, S., 2005. Sublimate speciation at Mutnovsky Volcano, Kamchatka. European Journal of Mineralogy 17, 107-118. 


\begin{tabular}{|c|c|c|c|c|}
\hline Mineral & Formula & Year & Max & Min \\
\hline Anglesite & $\mathrm{PbSO}_{4}$ & 2004 & 470 & 440 \\
\hline Anhydrite & $\mathrm{CaSO}_{4}$ & 2004 & 500 & 225 \\
\hline Arsenic & As & 2004 & 350 & 190 \\
\hline Barite & $\mathrm{BaSO}_{4}$ & 2004 & 470 & 460 \\
\hline Bismuthinite & $\mathrm{Bi}_{2} \mathrm{~S}_{3}$ & 2006 & 500 & 340 \\
\hline Challacolloite & $\mathrm{KPb}_{2} \mathrm{Cl}_{5}$ & 2006 & 560 & 320 \\
\hline Cotunnite & $\mathrm{PbCl}_{2}$ & 2006 & 590 & 300 \\
\hline Fe-Cr alloy & $\mathrm{Fe}, \mathrm{Cr}$ & 2006 & 590 & 340 \\
\hline Galena & $\mathrm{PbS}$ & 2006 & 560 & 300 \\
\hline Halite & $\mathrm{NaCl}$ & 2004,2006 & 580 & 420 \\
\hline Hematite & $\mathrm{Fe}_{2} \mathrm{O}_{3}$ & 2004,2006 & 600 & 320 \\
\hline Ilmenite & $\mathrm{FeTiO}_{3}$ & 2004 & 470 & 460 \\
\hline Penfieldite & $\mathrm{Pb}_{2} \mathrm{Cl}_{3}(\mathrm{OH})$ & 2004 & 450 & 380 \\
\hline Powellite & $\mathrm{CaMoO}_{4}$ & 2004 & 470 & 460 \\
\hline Pyrite & $\mathrm{FeS}_{2}$ & 2006 & 590 & 300 \\
\hline Salamoniac & $\mathrm{NH}_{4} \mathrm{Cl}$ & 2004 & 420 & 190 \\
\hline Smythite & $\mathrm{Fe}_{9} \mathrm{~S}_{11}$ & 2006 & 480 & 380 \\
\hline Sulfur & $\mathrm{S}$ & 2004,2006 & 560 & 190 \\
\hline Sylvite & $\mathrm{KCl}$ & 2004,2006 & 580 & 440 \\
\hline Tsugaruite & $\mathrm{Pb}_{4} \mathrm{As}_{2} \mathrm{~S}_{7}$ & 2006 & 340 & 320 \\
\hline Wurtzite & $(\mathrm{Zn}, \mathrm{Cd}, \mathrm{Fe}) \mathrm{S}$ & 2006 & 590 & 340 \\
\hline Greenockite & $\mathrm{CdS}$ & 2006 & 590 & 340 \\
\hline
\end{tabular}




\begin{tabular}{|c|c|c|c|c|c|c|c|}
\hline magmatic system & type & $\mathrm{Na}$ & $\mathrm{Cu}$ & $\mathrm{Zn}$ & Mo & $\mathrm{Pb}$ & Reference \\
\hline Bajo de la Alumbrera Cu-Au porphyry & $b$ & 78000 & 6500 & & & 1420 & Seo et al., 2009 \\
\hline Bajo de la Alumbrera Cu-Au porphyry & v & 24000 & 1800 & & & 210 & Seo et al., 2009 \\
\hline Bajo de la alumbrera Cu-Au porphyry & $\mathrm{b}$ & 160000 & 7600 & 14000 & 70 & 4500 & Ulrich et al., 1999 \\
\hline Bajo de la alumbrera Cu-Au porphyry & $\mathrm{v}$ & 17000 & 33000 & 1200 & & 200 & Ulrich et al., 1999 \\
\hline Bajo de la alumbrera Cu-Au porphyry & $\mathrm{b}$ & 106000 & 100 & 6000 & 140 & 1700 & Ulrich et al., 2002 \\
\hline Bajo de la alumbrera Cu-Au porphyry & b & 50000 & 300 & 6000 & & 1800 & Ulrich et al., 2002 \\
\hline Bajo de la alumbrera Cu-Au porphyry & $b$ & 92000 & 200 & & & & Ulrich et al., 2002 \\
\hline Bajo de la alumbrera Cu-Au porphyry & $\mathrm{b}$ & 105000 & 100 & 6000 & 30 & 2000 & Ulrich et al., 2002 \\
\hline Bajo de la alumbrera Cu-Au porphyry & $\mathrm{b}$ & 219000 & 1700 & & & & Ulrich et al., 2002 \\
\hline Bajo de la alumbrera Cu-Au porphyry & $\mathrm{b}$ & 105000 & 10000 & 18300 & 220 & 4400 & Ulrich et al., 2002 \\
\hline Bajo de la alumbrera Cu-Au porphyry & $\mathrm{b}$ & 243000 & 3700 & & & & Ulrich et al., 2002 \\
\hline Bajo de la alumbrera Cu-Au porphyry & b & 252000 & 2300 & 20 & & & Ulrich et al., 2002 \\
\hline Bajo de la alumbrera Cu-Au porphyry & $b$ & 124000 & 4800 & 7400 & 70 & 3300 & Ulrich et al., 2002 \\
\hline Bajo de la alumbrera Cu-Au porphyry & $b$ & 100000 & 500 & 8900 & & 2800 & Ulrich et al., 2002 \\
\hline Bajo de la alumbrera Cu-Au porphyry & b & 107000 & 1200 & 12000 & 120 & 3600 & Ulrich et al., 2002 \\
\hline Bajo de la alumbrera Cu-Au porphyry & $b$ & 123000 & 2200 & 4600 & & 1600 & Ulrich et al., 2002 \\
\hline Bajo de la alumbrera Cu-Au porphyry & $\mathrm{b}$ & 81000 & 3200 & 9500 & 40 & 2600 & Ulrich et al., 2002 \\
\hline Bajo de la alumbrera Cu-Au porphyry & b & 65000 & 3200 & 6000 & 80 & 1500 & Ulrich et al., 2002 \\
\hline Bajo de la alumbrera Cu-Au porphyry & $b$ & 198000 & 1000 & & & & Ulrich et al., 2002 \\
\hline Bajo de la alumbrera Cu-Au porphyry & $\mathrm{b}$ & 80000 & 5500 & 9900 & 90 & 2400 & Ulrich et al., 2002 \\
\hline Bajo de la alumbrera Cu-Au porphyry & b & 110000 & 2600 & 5400 & 130 & 1700 & Ulrich et al., 2002 \\
\hline Bajo de la alumbrera Cu-Au porphyry & $b$ & 104000 & 2000 & 9000 & 60 & 2000 & Ulrich et al., 2002 \\
\hline Bajo de la alumbrera Cu-Au porphyry & $b$ & 100000 & 5200 & 5700 & 50 & 1800 & Ulrich et al., 2002 \\
\hline Bajo de la alumbrera Cu-Au porphyry & b & 97000 & 700 & 5000 & & 1200 & Ulrich et al., 2002 \\
\hline Bajo de la alumbrera Cu-Au porphyry & $b$ & 100000 & 500 & 1200 & & 1500 & Ulrich et al., 2002 \\
\hline Bajo de la alumbrera Cu-Au porphyry & $b$ & 33000 & & 1000 & & 200 & Ulrich et al., 2002 \\
\hline Bajo de la alumbrera Cu-Au porphyry & b & 20000 & 300 & 1300 & & 1600 & Ulrich et al., 2002 \\
\hline Bajo de la alumbrera Cu-Au porphyry & $b$ & 9500 & 100 & 200 & & 90 & Ulrich et al., 2002 \\
\hline Bajo de la alumbrera Cu-Au porphyry & $\mathrm{b}$ & 4700 & & 300 & & 110 & Ulrich et al., 2002 \\
\hline Bajo de la alumbrera Cu-Au porphyry & $v$ & 11000 & 500 & & & & Ulrich et al., 2002 \\
\hline Bajo de la alumbrera Cu-Au porphyry & $v$ & 3000 & 1100 & 200 & & 70 & Ulrich et al., 2002 \\
\hline Bajo de la alumbrera Cu-Au porphyry & v & 7000 & 900 & 700 & & 200 & Ulrich et al., 2002 \\
\hline Bajo de la alumbrera Cu-Au porphyry & $\mathrm{v}$ & 11000 & 1200 & 400 & & 140 & Ulrich et al., 2002 \\
\hline Bajo de la alumbrera Cu-Au porphyry & $v$ & 3000 & 300 & 100 & & 30 & Ulrich et al., 2002 \\
\hline Bajo de la alumbrera Cu-Au porphyry & $\mathrm{v}$ & 6000 & 3000 & 300 & & 100 & Ulrich et al., 2002 \\
\hline Bajo de la alumbrera Cu-Au porphyry & $v$ & 14000 & 6000 & 800 & & 170 & Ulrich et al., 2002 \\
\hline Bajo de la alumbrera Cu-Au porphyry & $v$ & 9800 & 2500 & 1000 & & 250 & Ulrich et al., 2002 \\
\hline Bajo de la alumbrera Cu-Au porphyry & v & 30000 & 30000 & 6800 & & 620 & Ulrich et al., 2002 \\
\hline Bajo de la alumbrera Cu-Au porphyry & $\mathrm{v}$ & 13000 & 29000 & 1000 & & 40 & Ulrich et al., 2002 \\
\hline Bajo de la alumbrera Cu-Au porphyry & $v$ & 21000 & 26000 & 1300 & & 180 & Ulrich et al., 2002 \\
\hline Bajo de la alumbrera Cu-Au porphyry & $\mathrm{v}$ & 17000 & 33000 & 1200 & & 230 & Ulrich et al., 2002 \\
\hline Bajo de la alumbrera Cu-Au porphyry & $v$ & 7900 & 5200 & & & & Ulrich et al., 2002 \\
\hline Bajo de la alumbrera Cu-Au porphyry & $\mathrm{v}$ & 3900 & 1800 & & & & Ulrich et al., 2002 \\
\hline Bajo de la alumbrera Cu-Au porphyry & $v$ & 3900 & 500 & & & & Ulrich et al., 2002 \\
\hline Bajo de la alumbrera Cu-Au porphyry & $v$ & 3900 & 1700 & & & & Ulrich et al., 2002 \\
\hline Bingham Cu-Au-Mo porphyry & b & 123000 & 26000 & 2900 & 45 & 2400 & Landtwing et al., 2005 \\
\hline Bingham Cu-Au-Mo porphyry & $b$ & 102000 & 22000 & 4100 & 270 & 3800 & Landtwing et al., 2005 \\
\hline
\end{tabular}




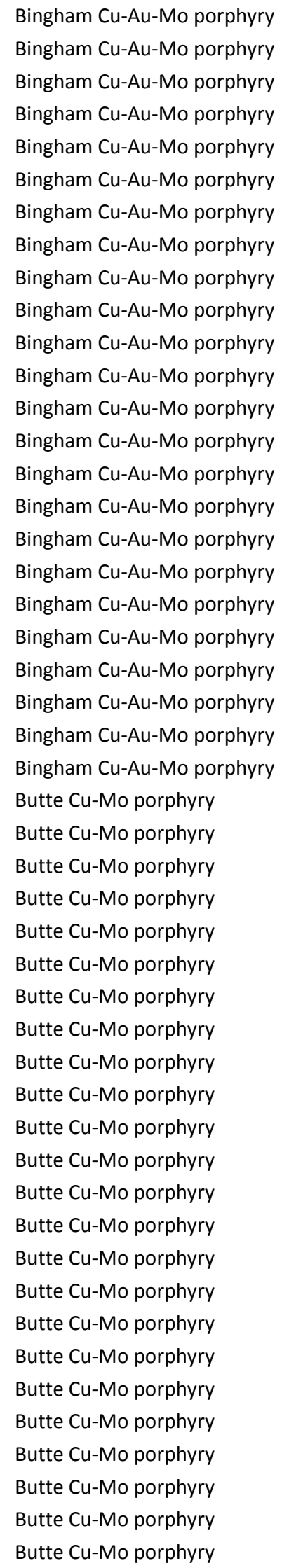

\begin{tabular}{|c|c|c|c|c|c|c|}
\hline b & 108000 & 15000 & 2800 & 94 & 3800 & Landtwing et al., 2005 \\
\hline b & 132000 & 15000 & 2700 & 60 & 3100 & Landtwing et al., 2005 \\
\hline$b$ & 112000 & 6200 & 4400 & & 3600 & Landtwing et al., 2005 \\
\hline b & 113000 & 3500 & 3500 & 1060 & 2900 & Landtwing et al., 2005 \\
\hline b & 125000 & 3200 & 3300 & 400 & 3300 & Landtwing et al., 2005 \\
\hline b & 110000 & 2500 & 4500 & 70 & 3700 & Landtwing et al., 2005 \\
\hline b & 113000 & 2100 & 3800 & 140 & 3300 & Landtwing et al., 2005 \\
\hline b & 107000 & 1300 & 4000 & 620 & 4100 & Landtwing et al., 2005 \\
\hline b & 123000 & 700 & 2100 & & 2100 & Landtwing et al., 2005 \\
\hline b & 116000 & 600 & 2100 & & 1800 & Landtwing et al., 2005 \\
\hline b & 102000 & 400 & 3700 & 44 & 2900 & Landtwing et al., 2005 \\
\hline b & 116000 & 8100 & 2500 & 150 & 3800 & Landtwing et al., 2005 \\
\hline b & 106000 & 7100 & 3100 & 49 & 3200 & Landtwing et al., 2005 \\
\hline$b$ & 980000 & 6520 & 3100 & & 3600 & Landtwing et al., 2005 \\
\hline$b$ & 105000 & 4500 & 3300 & & 2500 & Landtwing et al., 2005 \\
\hline b & 115000 & 3000 & 2200 & & 2000 & Landtwing et al., 2005 \\
\hline b & 960000 & 2000 & 3500 & 21 & 3200 & Landtwing et al., 2005 \\
\hline b & 112000 & 1450 & 2100 & & 2600 & Landtwing et al., 2005 \\
\hline b & 97000 & 7600 & & 450 & 2800 & Seo et al., 2009 \\
\hline b & 129000 & 18900 & & 33 & 3000 & Seo et al., 2009 \\
\hline b & 117000 & 1190 & & 88 & 3800 & Seo et al., 2009 \\
\hline$v$ & 16800 & 4200 & & 51 & 390 & Seo et al., 2009 \\
\hline$v$ & 23000 & 10800 & & 18.3 & 440 & Seo et al., 2009 \\
\hline v & 22000 & 300 & & 21 & 540 & Seo et al., 2009 \\
\hline b & 68000 & 5900 & 12000 & & 1200 & Rusk et al., 2004 \\
\hline b & 110000 & 170 & 3300 & & 1000 & Rusk et al., 2004 \\
\hline b & 100000 & & 5600 & & 1000 & Rusk et al., 2004 \\
\hline b & 55000 & & 9500 & & & Rusk et al., 2004 \\
\hline b & 100000 & 380 & 4700 & & 1000 & Rusk et al., 2004 \\
\hline b & 110000 & 81 & 4000 & & 860 & Rusk et al., 2004 \\
\hline b & 110000 & 1000 & 4300 & & 1100 & Rusk et al., 2004 \\
\hline b & 91000 & 800 & 5800 & & 810 & Rusk et al., 2004 \\
\hline b & 100000 & 1100 & 4500 & & 800 & Rusk et al., 2004 \\
\hline b & 80000 & 88 & 6900 & & 1300 & Rusk et al., 2004 \\
\hline$b$ & 100000 & 140 & 8300 & & 1600 & Rusk et al., 2004 \\
\hline b & 97000 & 440 & 12000 & & 2000 & Rusk et al., 2004 \\
\hline b & 83000 & 150 & 9800 & & 1400 & Rusk et al., 2004 \\
\hline b & 96000 & 760 & 15000 & & 1700 & Rusk et al., 2004 \\
\hline b & 97000 & & 7900 & & 1300 & Rusk et al., 2004 \\
\hline b & 74000 & & 6400 & & 840 & Rusk et al., 2004 \\
\hline b & 91000 & 850 & 7100 & 16 & 1500 & Rusk et al., 2004 \\
\hline b & 100000 & 2400 & 2800 & & 790 & Rusk et al., 2004 \\
\hline SC & 6300 & 4400 & 130 & & 32 & Rusk et al., 2004 \\
\hline sc & 7800 & 2100 & & & & Rusk et al., 2004 \\
\hline sc & 6100 & 3800 & 64 & & & Rusk et al., 2004 \\
\hline SC & 7800 & 3400 & 170 & 5 & 20 & Rusk et al., 2004 \\
\hline sc & 5900 & 5600 & 100 & & 8 & Rusk et al., 2004 \\
\hline sc & 6500 & 5600 & 150 & & 24 & Rusk et al., 2004 \\
\hline
\end{tabular}




\begin{tabular}{|c|c|c|c|c|c|c|c|}
\hline Butte Cu-Mo porphyry & sc & 5200 & 3800 & 140 & & 10 & Rusk et al., 2004 \\
\hline Butte Cu-Mo porphyry & sc & 6300 & 10100 & 140 & & 35 & Rusk et al., 2004 \\
\hline Butte Cu-Mo porphyry & sc & 4000 & 13400 & 81 & & & Rusk et al., 2004 \\
\hline Butte Cu-Mo porphyry & sc & 5100 & 6600 & 120 & & 19 & Rusk et al., 2004 \\
\hline Butte Cu-Mo porphyry & sc & 8900 & 1100 & 28 & & & Rusk et al., 2004 \\
\hline Butte Cu-Mo porphyry & sc & 6500 & 6000 & 100 & & 9 & Rusk et al., 2004 \\
\hline Butte Cu-Mo porphyry & sc & 8200 & 1800 & 160 & & 19 & Rusk et al., 2004 \\
\hline Butte Cu-Mo porphyry & sc & 6700 & 2200 & & & & Rusk et al., 2004 \\
\hline Butte Cu-Mo porphyry & sc & 8100 & 1500 & 170 & & & Rusk et al., 2004 \\
\hline Butte Cu-Mo porphyry & sc & 8600 & 1200 & 150 & 8 & 14 & Rusk et al., 2004 \\
\hline Butte Cu-Mo porphyry & sc & 6900 & 5000 & 160 & & 22 & Rusk et al., 2004 \\
\hline Butte Cu-Mo porphyry & sc & 6600 & 3600 & 160 & & 17 & Rusk et al., 2004 \\
\hline Butte Cu-Mo porphyry & sc & 7800 & 2300 & 110 & & 22 & Rusk et al., 2004 \\
\hline Butte Cu-Mo porphyry & sc & 7900 & 2200 & 170 & & 23 & Rusk et al., 2004 \\
\hline Butte Cu-Mo porphyry & sc & 10000 & 51 & 43 & & 30 & Rusk et al., 2004 \\
\hline Butte Cu-Mo porphyry & sc & 4300 & 2000 & 140 & & 11 & Rusk et al., 2004 \\
\hline Butte Cu-Mo porphyry & sc & 8800 & 320 & 100 & & 48 & Rusk et al., 2004 \\
\hline Butte Cu-Mo porphyry & sc & 5200 & 2300 & 100 & & 9 & Rusk et al., 2004 \\
\hline Butte Cu-Mo porphyry & sc & 6400 & 160 & 90 & & 15 & Rusk et al., 2004 \\
\hline Butte Cu-Mo porphyry & sc & 8200 & 130 & 140 & & 58 & Rusk et al., 2004 \\
\hline Butte Cu-Mo porphyry & sc & 8000 & 1000 & & & & Rusk et al., 2004 \\
\hline Butte Cu-Mo porphyry & sc & 7600 & 1200 & 100 & & & Rusk et al., 2004 \\
\hline Butte Cu-Mo porphyry & sc & 13000 & & 230 & & 76 & Rusk et al., 2004 \\
\hline Butte Cu-Mo porphyry & sc & 7200 & 940 & 190 & & 93 & Rusk et al., 2004 \\
\hline Butte Cu-Mo porphyry & sc & 9400 & 600 & 340 & & 62 & Rusk et al., 2004 \\
\hline Butte Cu-Mo porphyry & sc & 5700 & 12000 & 200 & & 50 & Rusk et al., 2004 \\
\hline Butte Cu-Mo porphyry & sc & 7000 & 9900 & 140 & & & Rusk et al., 2004 \\
\hline Butte Cu-Mo porphyry & sc & 5800 & 10000 & 460 & 37 & 63 & Rusk et al., 2004 \\
\hline Butte Cu-Mo porphyry & sc & 9100 & 3100 & 560 & 38 & 83 & Rusk et al., 2004 \\
\hline Butte Cu-Mo porphyry & sc & 8700 & 2200 & 390 & & 48 & Rusk et al., 2004 \\
\hline Butte Cu-Mo porphyry & sc & 7900 & 5000 & 300 & 343 & 66 & Rusk et al., 2004 \\
\hline Butte Cu-Mo porphyry & sc & 6100 & 7300 & 240 & & 42 & Rusk et al., 2004 \\
\hline Butte Cu-Mo porphyry & sc & 10000 & 360 & & & 61 & Rusk et al., 2004 \\
\hline Butte Cu-Mo porphyry & sc & 6000 & 12000 & & & 77 & Rusk et al., 2004 \\
\hline Butte Cu-Mo porphyry & sc & 9800 & & 60 & & 26 & Rusk et al., 2004 \\
\hline Butte Cu-Mo porphyry & sc & 8100 & 4300 & 290 & & 46 & Rusk et al., 2004 \\
\hline Butte Cu-Mo porphyry & sc & 8600 & 1800 & 690 & & 63 & Rusk et al., 2004 \\
\hline Butte Cu-Mo porphyry & sc & 8600 & 4400 & 110 & & 52 & Rusk et al., 2004 \\
\hline Butte Cu-Mo porphyry & sc & 8100 & 5200 & & & 59 & Rusk et al., 2004 \\
\hline Butte Cu-Mo porphyry & sc & 7100 & 11000 & 70 & & 35 & Rusk et al., 2004 \\
\hline Butte Cu-Mo porphyry & sc & 8300 & 7900 & & & & Rusk et al., 2004 \\
\hline Butte Cu-Mo porphyry & sc & 8500 & 3400 & 1500 & & 35 & Rusk et al., 2004 \\
\hline Butte Cu-Mo porphyry & sc & 9700 & 330 & 470 & & 100 & Rusk et al., 2004 \\
\hline Butte Cu-Mo porphyry & sc & 10000 & & & & 54 & Rusk et al., 2004 \\
\hline Butte Cu-Mo porphyry & sc & 6500 & 11000 & 210 & & 52 & Rusk et al., 2004 \\
\hline Butte Cu-Mo porphyry & sc & 9600 & 890 & 300 & & 88 & Rusk et al., 2004 \\
\hline Butte Cu-Mo porphyry & sc & 6900 & 10000 & 210 & & 44 & Rusk et al., 2004 \\
\hline Butte Cu-Mo porphyry & sc & 8600 & 1300 & 640 & & 81 & Rusk et al., 2004 \\
\hline
\end{tabular}




\begin{abstract}
Butte Cu-Mo porphyry
Butte Cu-Mo porphyry

Butte Cu-Mo porphyry

Butte Cu-Mo porphyry

Butte Cu-Mo porphyry

Butte Cu-Mo porphyry

Butte Cu-Mo porphyry

Butte Cu-Mo porphyry

Butte Cu-Mo porphyry

Butte Cu-Mo porphyry

Butte Cu-Mo porphyry

Butte Cu-Mo porphyry

El Teniente porphyry Cu-Mo

El Teniente porphyry Cu-Mo

El Teniente porphyry Cu-Mo

El Teniente porphyry Cu-Mo

El Teniente porphyry Cu-Mo

El Teniente porphyry Cu-Mo

El Teniente porphyry Cu-Mo

El Teniente porphyry Cu-Mo

El Teniente porphyry Cu-Mo

El Teniente porphyry Cu-Mo

El Teniente porphyry Cu-Mo

El Teniente porphyry Cu-Mo

El Teniente porphyry Cu-Mo

El Teniente porphyry Cu-Mo

El Teniente porphyry Cu-Mo

El Teniente porphyry Cu-Mo

El Teniente porphyry Cu-Mo

El Teniente porphyry Cu-Mo

El Teniente porphyry Cu-Mo

El Teniente porphyry Cu-Mo

El Teniente porphyry Cu-Mo

El Teniente porphyry Cu-Mo

El Teniente porphyry Cu-Mo

El Teniente porphyry Cu-Mo

El Teniente porphyry Cu-Mo

El Teniente porphyry Cu-Mo

El Teniente porphyry Cu-Mo

El Teniente porphyry Cu-Mo

El Teniente porphyry Cu-Mo

El Teniente porphyry Cu-Mo

El Teniente porphyry Cu-Mo

El Teniente porphyry Cu-Mo

El Teniente porphyry Cu-Mo

El Teniente porphyry Cu-Mo

El Teniente porphyry Cu-Mo

El Teniente porphyry Cu-Mo
\end{abstract}

\begin{tabular}{|c|c|c|c|c|c|c|}
\hline SC & 8900 & 4600 & & & 40 & Rusk et al., 2004 \\
\hline SC & 6200 & 18000 & 1600 & & 75 & Rusk et al., 2004 \\
\hline SC & 7200 & 12000 & 300 & & 23 & Rusk et al., 2004 \\
\hline SC & 7700 & 13000 & & 42 & 61 & Rusk et al., 2004 \\
\hline SC & 10000 & 5500 & & & & Rusk et al., 2004 \\
\hline & 7100 & 15000 & 210 & & & Rusk et al., 2004 \\
\hline כ & 9900 & 7200 & 200 & & 100 & Rusk et al., 2004 \\
\hline SC & 12000 & 2100 & & & & Rusk et al., 2004 \\
\hline SC & 9500 & 8100 & 330 & & 68 & Rusk et al., 2004 \\
\hline SC & 4500 & 18000 & 350 & & 59 & Rusk et al., 2004 \\
\hline SC & 6400 & 14000 & 270 & & 56 & Rusk et al., 2004 \\
\hline SC & 7900 & 8000 & 1100 & & & Rusk et al., 2004 \\
\hline b & 96900 & 820 & 2600 & 4 & 650 & Klemm et al., 2007 \\
\hline b & 112400 & 450 & 2600 & 11 & 520 & Klemm et al., 2007 \\
\hline b & 104600 & 260 & 6600 & 8 & 2100 & Klemm et al., 2007 \\
\hline b & 139500 & 9600 & 4800 & 17 & 760 & Klemm et al., 2007 \\
\hline b & 92400 & 4900 & 4400 & 12 & 1000 & Klemm et al., 2007 \\
\hline b & 86600 & 2800 & 4100 & 55 & 750 & Klemm et al., 2007 \\
\hline$b$ & 114200 & 5000 & 4300 & 760 & 620 & Klemm et al., 2007 \\
\hline b & 152000 & 4600 & 1300 & 660 & 460 & Klemm et al., 2007 \\
\hline b & 159800 & 7900 & 1700 & 1200 & 610 & Klemm et al., 2007 \\
\hline b & 200700 & 3900 & 1100 & 830 & 220 & Klemm et al., 2007 \\
\hline b & 166200 & 29100 & 1400 & 1300 & 550 & Klemm et al., 2007 \\
\hline b & 176400 & 7400 & 1300 & 1000 & 520 & Klemm et al., 2007 \\
\hline b & 177600 & 4200 & & 1800 & 400 & Klemm et al., 2007 \\
\hline b & 189700 & 730 & & 610 & 610 & Klemm et al., 2007 \\
\hline b & 97800 & 400 & 1700 & 17 & 640 & Klemm et al., 2007 \\
\hline b & 81000 & 420 & 2300 & & 460 & Klemm et al., 2007 \\
\hline b & 75300 & 400 & 23700 & 8 & 800 & Klemm et al., 2007 \\
\hline b & 98400 & 620 & 910 & 120 & 270 & Klemm et al., 2007 \\
\hline b & 96100 & 2100 & 4500 & 60 & 1000 & Klemm et al., 2007 \\
\hline sc & 37800 & 370 & 1600 & 80 & 220 & Klemm et al., 2007 \\
\hline sc & 34700 & 1500 & 980 & 6 & 240 & Klemm et al., 2007 \\
\hline sc & 5400 & 1400 & 220 & & 50 & Klemm et al., 2007 \\
\hline SC & 8600 & 3300 & 240 & 15 & 40 & Klemm et al., 2007 \\
\hline sc & 10200 & 14400 & 300 & 17 & 50 & Klemm et al., 2007 \\
\hline sc & 13200 & 4300 & 220 & 8 & 50 & Klemm et al., 2007 \\
\hline sc & 5100 & 21100 & 110 & & 13 & Klemm et al., 2007 \\
\hline sc & 15400 & 4500 & 150 & 11 & 75 & Klemm et al., 2007 \\
\hline sc & 15500 & 2500 & & & 50 & Klemm et al., 2007 \\
\hline SC & 14400 & 2800 & 250 & & 65 & Klemm et al., 2007 \\
\hline sc & 11800 & 6200 & 270 & 6 & 55 & Klemm et al., 2007 \\
\hline sc & 17300 & 4600 & 460 & 8 & 75 & Klemm et al., 2007 \\
\hline sc & 8100 & 8700 & 120 & 7 & 19 & Klemm et al., 2007 \\
\hline SC & 20800 & 1700 & 190 & & 59 & Klemm et al., 2007 \\
\hline v & 8800 & 5800 & 260 & 60 & 35 & Klemm et al., 2007 \\
\hline v & 900 & 260 & 12 & 6 & 9 & Klemm et al., 2007 \\
\hline v & 2900 & 350 & 55 & 3 & 11 & Klemm et al., 2007 \\
\hline
\end{tabular}




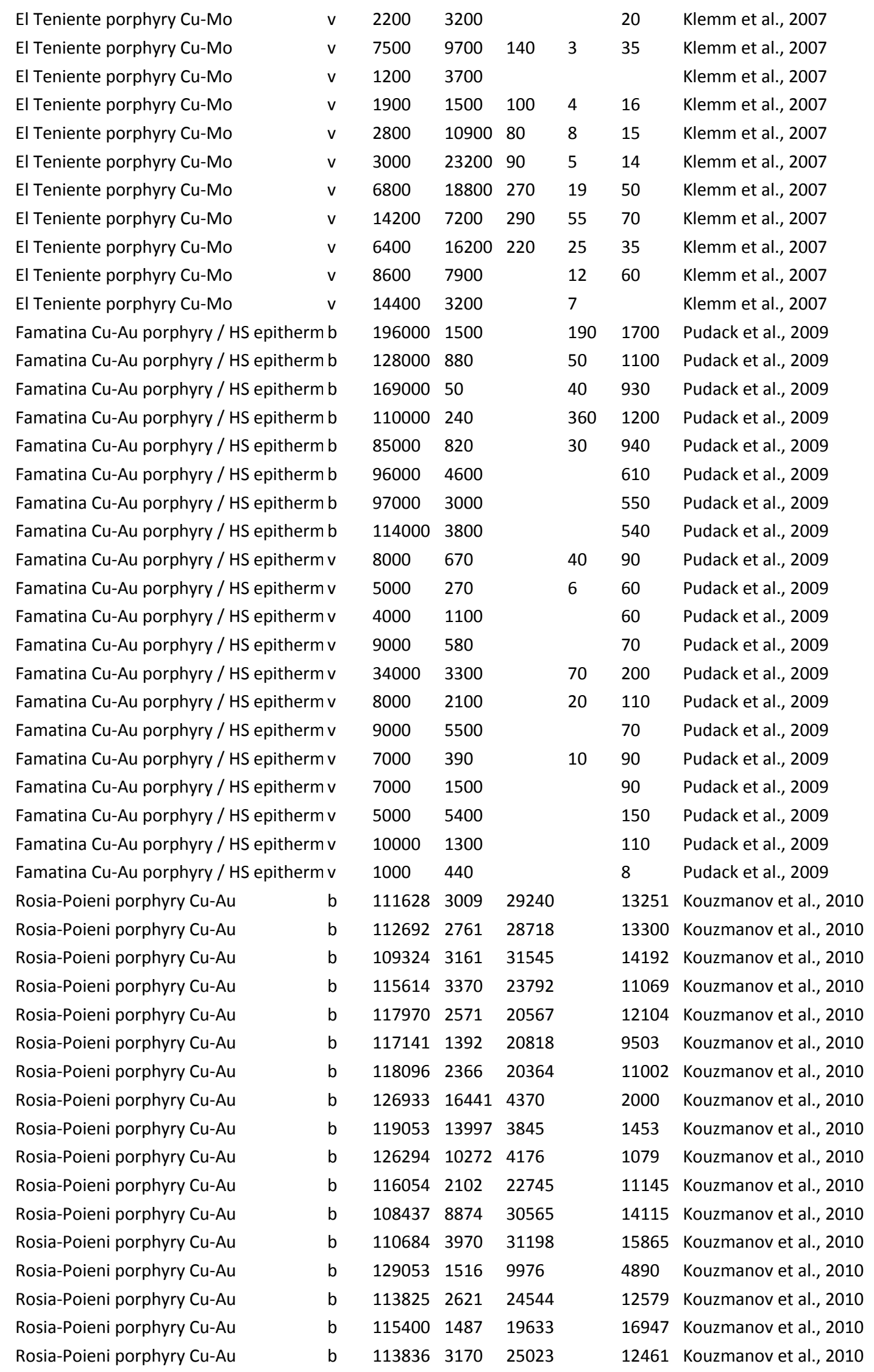


Rosia-Poieni porphyry $\mathrm{Cu}-\mathrm{Au}$ Rosia-Poieni porphyry $\mathrm{Cu}-\mathrm{Au}$ Rosia-Poieni porphyry $\mathrm{Cu}-\mathrm{Au}$ Rosia-Poieni porphyry $\mathrm{Cu}-\mathrm{Au}$ Rosia-Poieni porphyry $\mathrm{Cu}-\mathrm{Au}$ Rosia-Poieni porphyry $\mathrm{Cu}-\mathrm{Au}$ Rosia-Poieni porphyry $\mathrm{Cu}-\mathrm{Au}$ Rosia-Poieni porphyry $\mathrm{Cu}-\mathrm{Au}$ Rosia-Poieni porphyry Cu-Au Rosia-Poieni porphyry $\mathrm{Cu}-\mathrm{Au}$ Rosia-Poieni porphyry $\mathrm{Cu}-\mathrm{Au}$ Rosia-Poieni porphyry Cu-Au Rosia-Poieni porphyry $\mathrm{Cu}-\mathrm{Au}$ Rosia-Poieni porphyry $\mathrm{Cu}-\mathrm{Au}$ Rosia-Poieni porphyry $\mathrm{Cu}-\mathrm{Au}$ Rosia-Poieni porphyry Cu-Au Rosia-Poieni porphyry Cu-Au Rosia-Poieni porphyry $\mathrm{Cu}-\mathrm{Au}$ Rosia-Poieni porphyry $\mathrm{Cu}-\mathrm{Au}$ Rosia-Poieni porphyry $\mathrm{Cu}-\mathrm{Au}$ Rosia-Poieni porphyry $\mathrm{Cu}-\mathrm{Au}$ Rosia-Poieni porphyry $\mathrm{Cu}-\mathrm{Au}$ Rosia-Poieni porphyry $\mathrm{Cu}-\mathrm{Au}$ Rosia-Poieni porphyry $\mathrm{Cu}-\mathrm{Au}$ Rosia-Poieni porphyry $\mathrm{Cu}-\mathrm{Au}$ Rosia-Poieni porphyry $\mathrm{Cu}-\mathrm{Au}$ Rosia-Poieni porphyry $\mathrm{Cu}-\mathrm{Au}$ Rosia-Poieni porphyry $\mathrm{Cu}-\mathrm{Au}$ Rosia-Poieni porphyry Cu-Au Rosia-Poieni porphyry $\mathrm{Cu}-\mathrm{Au}$ Rosia-Poieni porphyry $\mathrm{Cu}-\mathrm{Au}$ Rosia-Poieni porphyry $\mathrm{Cu}-\mathrm{Au}$ Rosia-Poieni porphyry $\mathrm{Cu}-\mathrm{Au}$ Rosia-Poieni porphyry $\mathrm{Cu}-\mathrm{Au}$ Rosia-Poieni porphyry Cu-Au Rosia-Poieni porphyry $\mathrm{Cu}-\mathrm{Au}$ Rosia-Poieni porphyry $\mathrm{Cu}-\mathrm{Au}$ Rosia-Poieni porphyry Cu-Au Rosia-Poieni porphyry Cu-Au Rosia-Poieni porphyry $\mathrm{Cu}-\mathrm{Au}$ Rosia-Poieni porphyry $\mathrm{Cu}-\mathrm{Au}$ Rosia-Poieni porphyry Cu-Au Rosia-Poieni porphyry Cu-Au Santa Rita Cu (Mo-u) porphyry Santa Rita Cu (Mo-u) porphyry Santa Rita Cu (Mo-u) porphyry Santa Rita Cu (Mo-u) porphyry Santa Rita Cu (Mo-u) porphyry

$\begin{array}{lll}117696 & 2019 & 22070 \\ 120260 & 2314 & 16677 \\ 118632 & 1860 & 18853 \\ 119786 & & 13816 \\ 122163 & 1885 & 17538 \\ 119590 & 1317 & 21814 \\ 115808 & 1057 & 25452 \\ 105602 & 1748 & 39610 \\ 97573 & 2581 & 43213 \\ 107373 & 2986 & 35954 \\ 108885 & 3725 & 34765 \\ 109691 & 5232 & 34364 \\ 105348 & 5147 & 33324 \\ 94639 & 139 & 26504 \\ 101573 & 113 & 23176 \\ 101142 & 194 & 19817 \\ 107724 & 244 & 30213 \\ 105114 & 337 & 5946 \\ 101035 & 319 & 6591 \\ 102399 & 235 & 7808 \\ 96803 & 167 & 16573 \\ 1675 & & \\ 1642 & 30 & 31 \\ 1957 & & 24 \\ 1821 & & 3.5\end{array}$$$
1961
$$$$
1935
$$$$
1963
$$$$
1567
$$$$
1941
$$$$
785
$$$$
\text { v } 1664
$$$$
1386
$$$$
1617
$$$$
\text { v } 1952
$$$$
\text { v } 1014
$$$$
1870
$$$$
1936
$$$$
\text { v } 1967
$$$$
\text { v } 1226
$$$$
\text { v } 1816
$$$$
\text { v } 1581
$$$$
\text { v } 1252
$$

b $67900 \quad 2300 \quad 3400$

$\begin{array}{llll}68100 & 2700 \quad 2800\end{array}$

750002200

$74300 \quad 2800 \quad 2300$

7277 Kouzmanov et al., 2010

10056 Kouzmanov et al., 2010

10462 Kouzmanov et al., 2010

26325 Kouzmanov et al., 2010

10794 Kouzmanov et al., 2010

11815 Kouzmanov et al., 2010

14115 Kouzmanov et al., 2010

17722 Kouzmanov et al., 2010

20343 Kouzmanov et al., 2010

19660 Kouzmanov et al., 2010

19574 Kouzmanov et al., 2010

18912 Kouzmanov et al., 2010

17606 Kouzmanov et al., 2010

10189 Kouzmanov et al., 2010

10715 Kouzmanov et al., 2010

11812 Kouzmanov et al., 2010

17146 Kouzmanov et al., 2010

3760 Kouzmanov et al., 2010

4178 Kouzmanov et al., 2010

4189 Kouzmanov et al., 2010

4911 Kouzmanov et al., 2010 Kouzmanov et al., 2010

1.7 Kouzmanov et al., 2010 Kouzmanov et al., 2010 Kouzmanov et al., 2010

0.5 Kouzmanov et al., 2010

13 Kouzmanov et al., 2010 Kouzmanov et al., 2010

153 Kouzmanov et al., 2010

0.7 Kouzmanov et al., 2010 Kouzmanov et al., 2010

33 Kouzmanov et al., 2010

9.3 Kouzmanov et al., 2010

23 Kouzmanov et al., 2010

Kouzmanov et al., 2010 Kouzmanov et al., 2010

1.4 Kouzmanov et al., 2010

1.5 Kouzmanov et al., 2010

Kouzmanov et al., 2010

15 Kouzmanov et al., 2010

Kouzmanov et al., 2010

3.8 Kouzmanov et al., 2010

625 Kouzmanov et al., 2010

800 Audétat et al., 2008

590 Audétat et al., 2008

780 Audétat et al., 2008

830 Audétat et al., 2008

840 Audétat et al., 2008 
Santa Rita Cu (Mo-u) porphyry Santa Rita Cu (Mo-u) porphyry Santa Rita Cu (Mo-u) porphyry Santa Rita Cu (Mo-u) porphyry Santa Rita Cu (Mo-u) porphyry

$\begin{array}{lllllll}\text { b } & 64900 & 620 & & 380 & & \text { Audétat et al., 2008 } \\ \text { v } & 50000 & 7800 & 2500 & 5 & 410 & \text { Audétat et al., 2008 } \\ \text { v } & 50800 & 8800 & 1300 & & 390 & \text { Audétat et al., 2008 } \\ \text { v } & 28400 & 4100 & & & 200 & \text { Audétat et al., 2008 } \\ \text { v } & 50000 & 3800 & 1400 & 15 & 420 & \text { Audétat et al., 2008 }\end{array}$




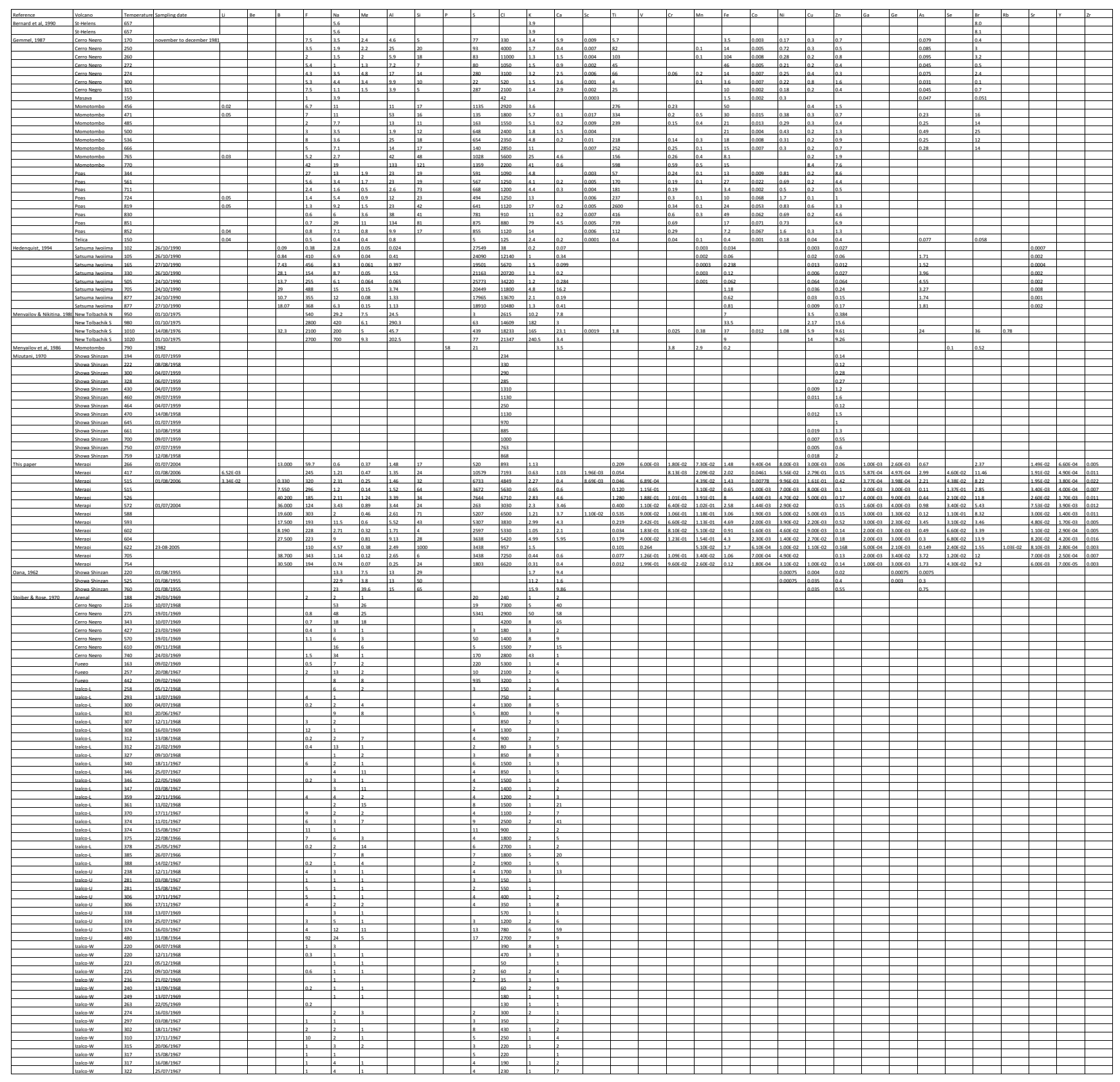




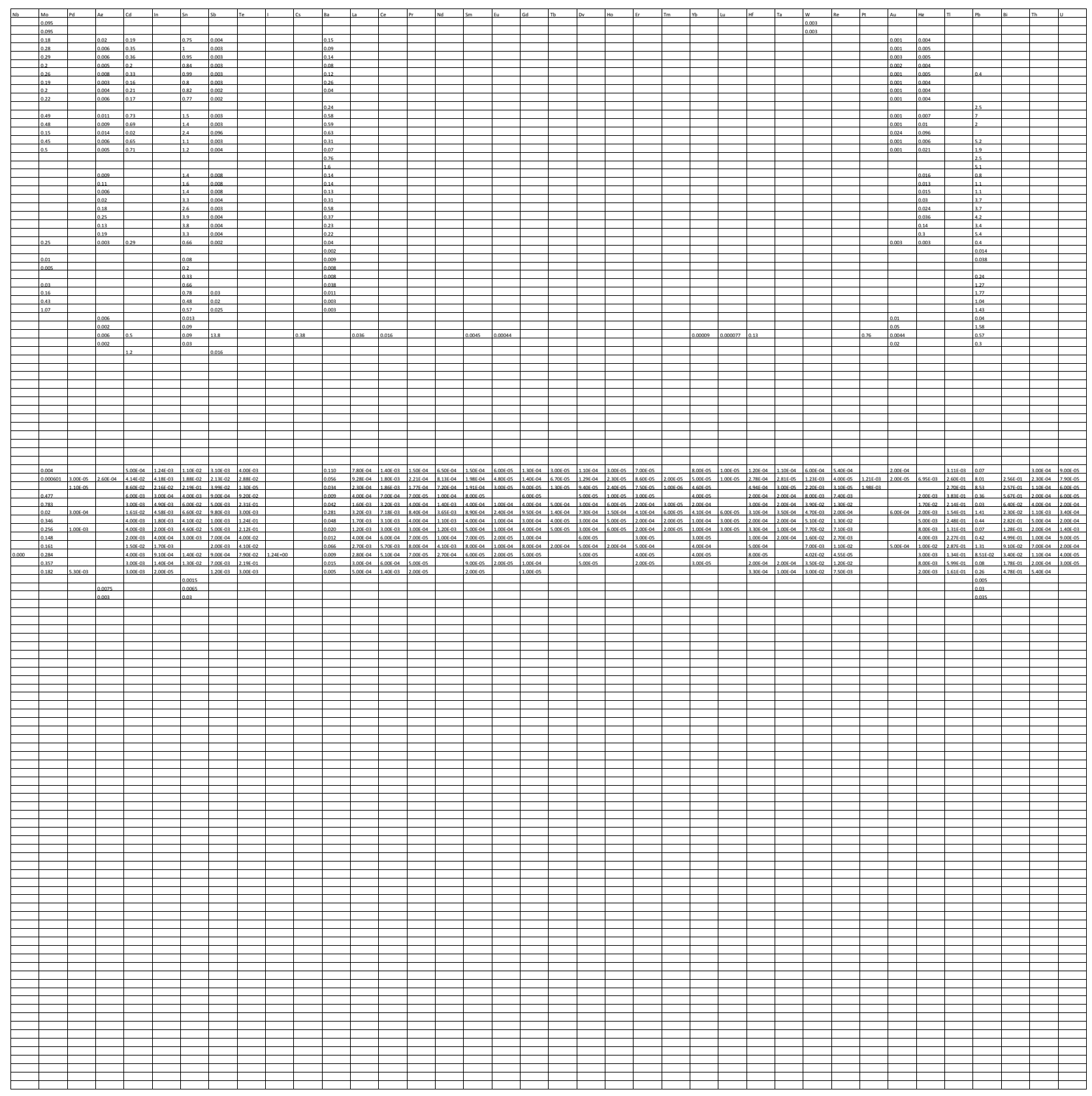




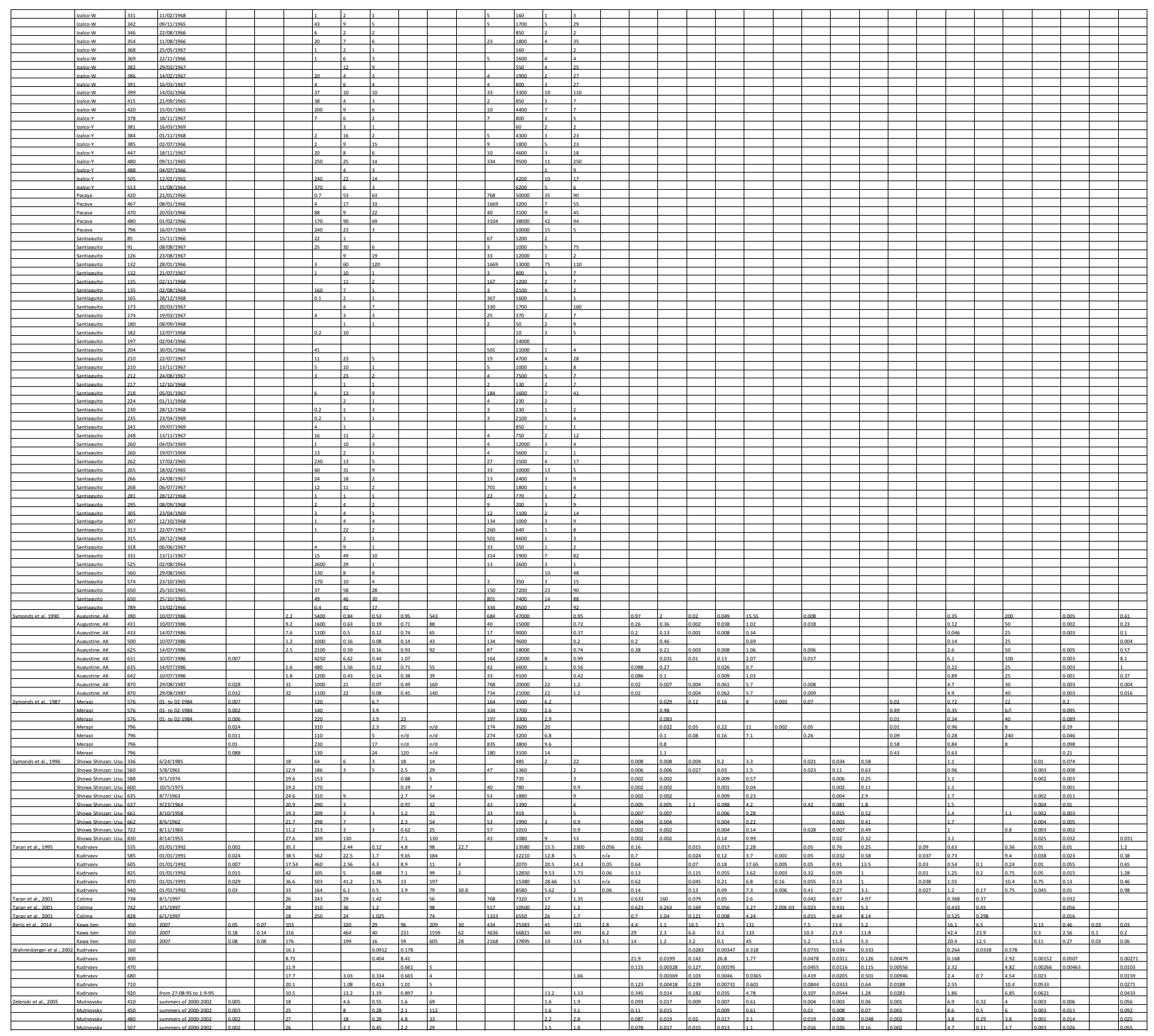




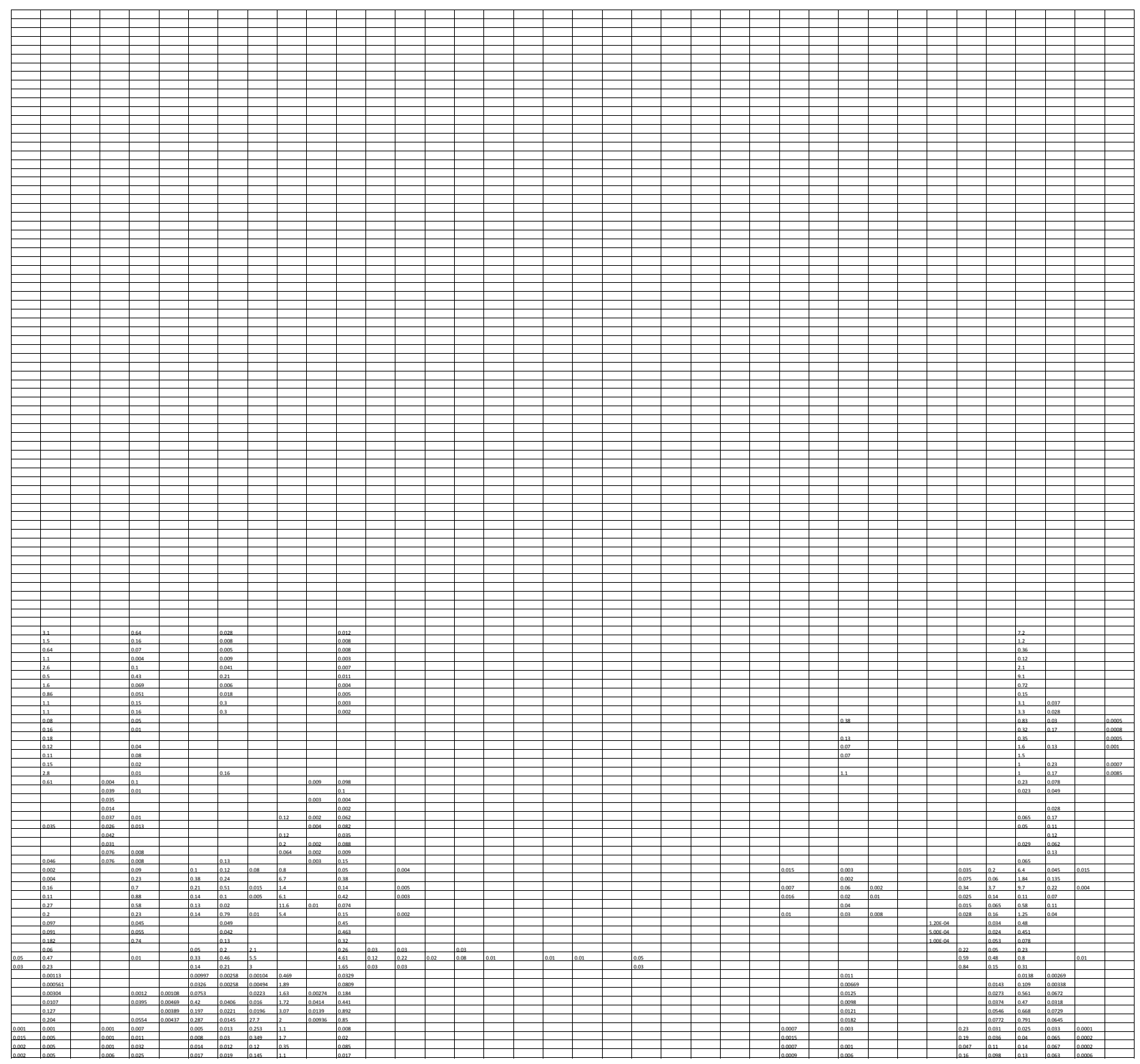

